\title{
Cultural Resources Survey for the City of Florence Municipal Facilities Complex Project, Williamson County, Texas
}

Christopher M. Shelton

Victoria J. Myers

Follow this and additional works at: https://scholarworks.sfasu.edu/ita

Part of the American Material Culture Commons, Archaeological Anthropology Commons, Environmental Studies Commons, Other American Studies Commons, Other Arts and Humanities Commons, Other History of Art, Architecture, and Archaeology Commons, and the United States History Commons

Tell us how this article helped you.

This Article is brought to you for free and open access by the Center for Regional Heritage Research at SFA ScholarWorks. It has been accepted for inclusion in Index of Texas Archaeology: Open Access Gray Literature from the Lone Star State by an authorized editor of SFA ScholarWorks. For more information, please contact cdsscholarworks@sfasu.edu. 


\section{Cultural Resources Survey for the City of Florence Municipal Facilities Complex Project, Williamson County, Texas}

\section{Creative Commons License}

\section{(c) (1) \&}

This work is licensed under a Creative Commons Attribution-NonCommercial 4.0 International License 


\section{Cultural Resources Survey for the City of Florence Municipal Facilities Complex Project, Williamson County, Texas}

TEXAS ANTIQUITIES PERMIT NO. 9142

APRIL 2020

PREPARED FOR

The City of Florence

PREPARED BY

SWCA Environmental Consultants 



\title{
CULTURAL RESOURCES SURVEY FOR THE CITY OF FLORENCE MUNICIPAL FACILITIES COMPLEX PROJECT, WILLIAMSON COUNTY, TEXAS
}

\author{
Prepared for \\ The City of Florence, Texas \\ 106 S. Patterson, \\ Florence, Texas 76527
}

\author{
Prepared by \\ Christopher M. Shelton, M.A., and Victoria J. Myers, M.A. \\ SWCA Environmental Consultants \\ 4407 Monterey Oaks Boulevard \\ Building 1, Suite 110 \\ Austin, Texas 78749 \\ www.swca.com \\ Principal Investigator \\ Christopher Shelton, M.A.
}

Antiquities Code of Texas Permit No. 9142

SWCA Project No. 57745

SWCA Cultural Resources Report No. 19-692

April 2020 
This page intentionally left blank. 


\section{ABSTRACT}

On behalf of the City of Florence, Texas, SWCA Environmental Consultants (SWCA) conducted an intensive cultural resources survey of the proposed City of Florence Municipal Facilities Complex (Project) in Williamson County, Texas. The 1.2-acre parcel scheduled for redevelopment is located on land owned and managed by the City of Florence, a political subdivision of the state of Texas; therefore, the Project requires compliance with the Antiquities Code of Texas (ACT). In addition, the project will receive federal funds from the U.S. Department of Agriculture (USDA); therefore, the work was conducted to comply with the National Historic Preservation Act (NHPA). This cultural resources investigation was conducted under ACT Permit No. 9142. On behalf of the USDA, SWCA has also issued engagement letters to the six Tribes identified by the U.S. Department of Housing and Urban Development (HUD) as having overlapping interest with the Project area. To date, SWCA has yet to receive comments from the identified Tribes.

The parcel on which the Project is proposed contains four extant buildings/structures: the Florence City Hall, the Chamber of Commerce, a large Veteran's Memorial, and a thrift store. As part of the Project, all but the Veteran's Memorial are scheduled for demolition and a larger municipal complex is expected to be constructed in their stead. Impacts are expected to include widespread surficial modifications with deeper impacts in locations of foundations and utilities.

The cultural resources investigation consisted of a background and historical map review followed by intensive pedestrian survey augmented by shovel testing conducted by an archaeologist, and an assessment of the extant buildings conducted by an architectural historian. SWCA's background review determined that there are no known cultural resources within the Project area. Additionally, the historical map review identified only two potential historical structures within the Project area.

During field investigations on September 25 and November 5, 2019, SWCA confirmed that the four extant buildings/structures on the subject property are of modern construction, and therefore, are not eligible for the National Register of Historic Places (NRHP) and are not considered eligible for designation as a State Antiquities Landmark (SAL). In addition, the two potential historical structures identified during the historical map review within the Project area are not extant. SWCA excavated a total of 12 shovel tests within the Project area, three of which were positive for cultural materials. The cultural material includes an axe head, an unidentifiable metal fragment, a round nail, and a white-bodied earthenware sherd. The artifacts found within the shovel tests cannot be securely identified as being from a historic origin and were found with, or near the same depth as, modern plastic fragments. Furthermore, the soils within the Project area exhibited a high degree of disturbance due to decades of construction, landscaping, and tree planting, as well as buried utilities. Due to the lack of soil integrity and the lack of artifacts that can securely be attributed to a historic origin, SWCA finds the three positive shovel tests as constituting an isolated find and does not rise to the level of an archaeological site. As such, the isolated finds do not meet the criteria for NRHP listing nor SAL designation. No other cultural resources were identified within the Project area.

In accordance with the ACT and with Section 106 of the NHPA (36 Code of Federal Regulations [CFR] 800.4 (b)(1)), SWCA has made a reasonable and good faith effort to identify historic properties within the area of potential effects. SWCA recommends a finding of No Historic Properties Affected per 36 CFR 800. 5(b) and no further archaeological investigation of the current Project area is recommended. No artifacts or samples were collected during this survey. All survey-related documentation will be curated at the Center for Archaeological Studies, Texas State University, San Marcos, Texas. 
This page intentionally left blank. 


\section{CONTENTS}

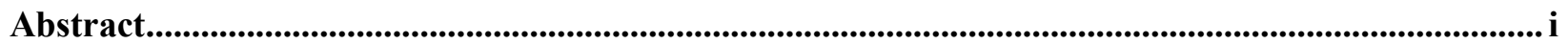

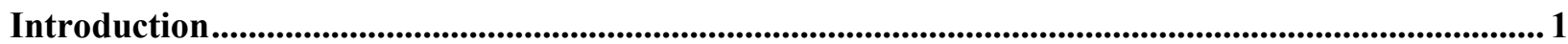

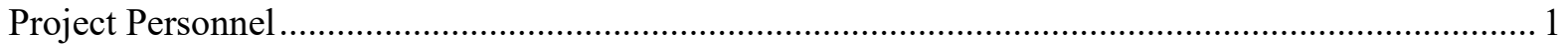

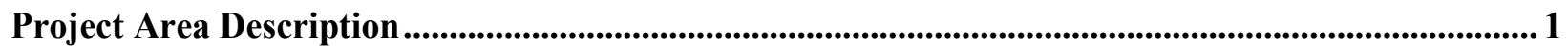

Geology

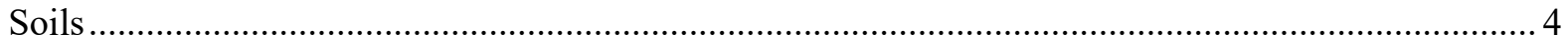

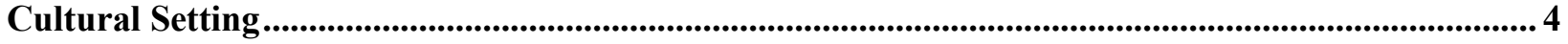

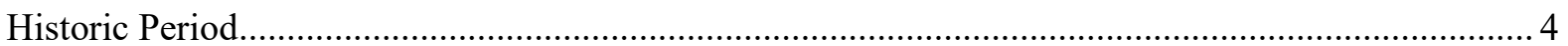

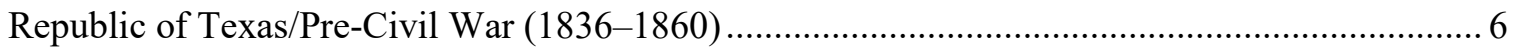

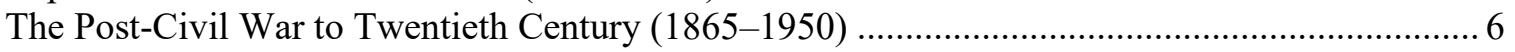

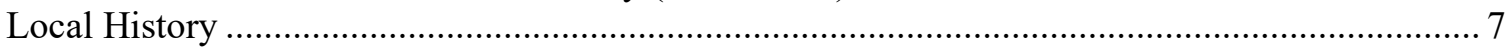

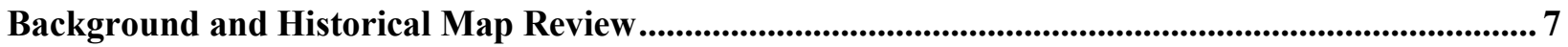

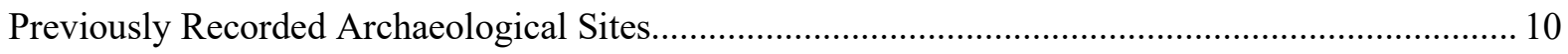

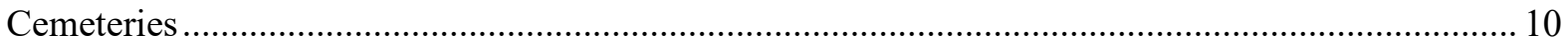

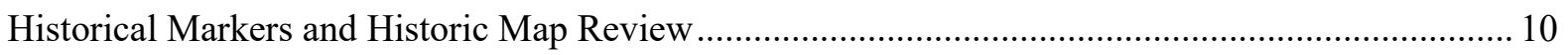

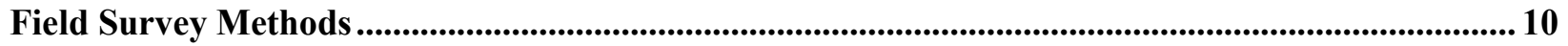

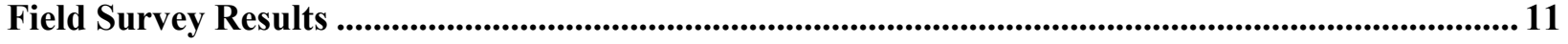

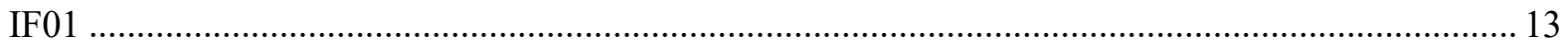

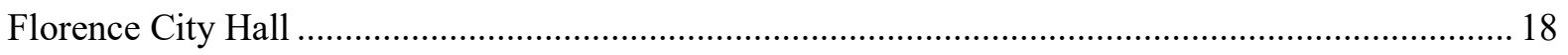

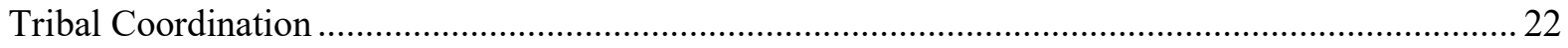

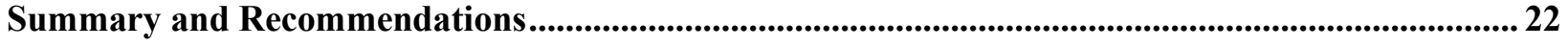

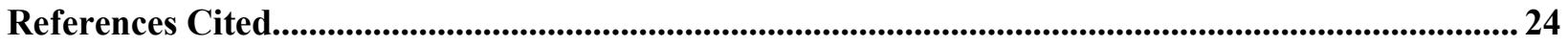

\section{Appendices}

APPENDIX A. Unanticipated Discoveries Plan 


\section{Figures}

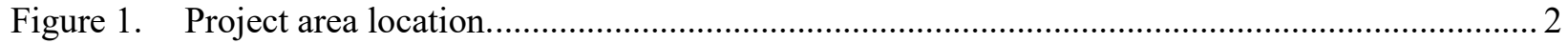

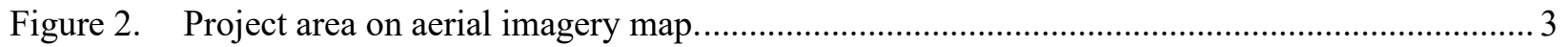

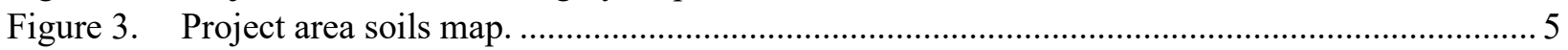

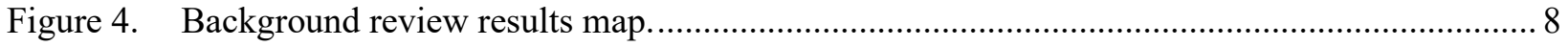

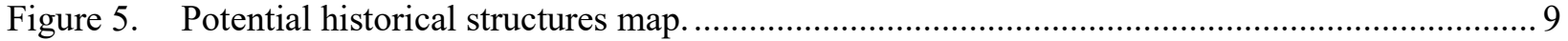

Figure 6. Buildings/Structures within the Project area..................................................................... 12

Figure 7. Example of extensive soil disturbance due to building, foundation, and parking lot

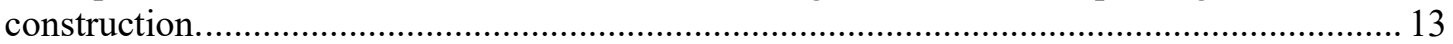

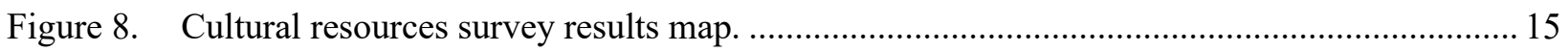

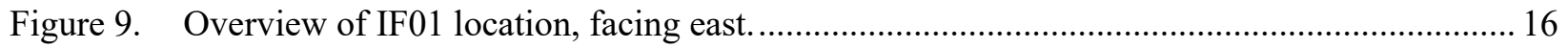

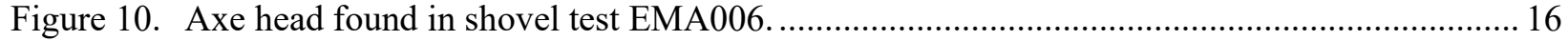

Figure 11. White-bodied earthenware sherd found in shovel test EMA007..................................... 17

Figure 12. Oxidized nail and modern sprinkler head found together in shovel test EMA009................ 17

Figure 13. Florence City Hall, oblique, east (front) and south elevations, facing northwest................... 18

Figure 14. Storage building, oblique, east (front) and south elevations, facing northwest..................... 19

Figure 15. Veteran's Memorial, facing west................................................................................. 19

Figure 16. Chamber of Commerce, oblique, east (front) and south elevations, facing northwest. ...........20

Figure 17. Historic-age residence immediately north of project area, south (front) elevation, facing

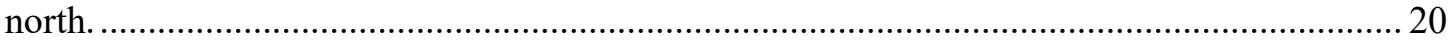

Figure 18. Historic-age residence immediately south of project area, east (front) elevation, facing

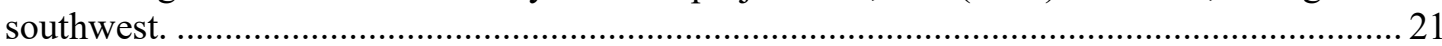

Figure 19. Main Street, view from northeast corner of project area, facing east ................................. 21

Figure 20. Modern bank building, corner of Main and Patterson, east of project area, west elevation, facing east.

\section{Tables}

Table 1. Shovel Test Data 


\section{INTRODUCTION}

On behalf of the City of Florence in Williamson County, Texas, SWCA Environmental Consultants (SWCA) conducted an intensive cultural resources survey of the proposed City of Florence Municipal Facilities Complex (Project) (Figure 1). The Project involves the construction of a new municipal complex within a 1.2-acre lot that currently contains the existing Florence City Hall, a thrift shop, a Veteran's Memorial, and the Florence Chamber of Commerce (Figure 2). As the Project involves lands owned or controlled by the City of Florence (a subdivision of the State of Texas), the Project is subject to review under the Antiquities Code of Texas (ACT). In addition, the project will receive federal funds from the U.S. Department of Agriculture; therefore, the work was conducted to comply with the National Historic Preservation Act (NHPA). The cultural resources investigation was conducted under ACT Permit No. 9142.

The goal of this investigation was to locate all prehistoric and historic cultural resources within the Project area, establish vertical and horizontal site boundaries, as appropriate, within the Project area, and evaluate the significance and eligibility of cultural resources for designation as State Antiquities Landmarks (SALs) and for the National Register of Historic Places (NRHP). This investigation complied with Secretary of Interior standards and followed the guidelines and procedures outlined in the Council of Texas Archeologists (CTA) standards for cultural resources investigations and the ACT, as outlined in the Texas Historical Commission's (THC's) Rules of Practice and Procedure for the Antiquities Code of Texas.

\section{Project Personnel}

Christopher Shelton, M.A., served as the Principal Investigator for the duration of the Project, overseeing overall logistics and organization, managing reporting, and agency consultation. Architectural Historian Victoria J. Myers, M.A., completed the structural survey on September 25, 2019. Archaeologist Edward Arevalo, B.A., completed the archaeological survey on November 5, 2019. Liz Hitzfelder produced field and report maps for the Project, and Lauri Logan provided technical editing and document preparation.

\section{PROJECT AREA DESCRIPTION}

The approximately 1.2-acre Project area appears on portions of the Florence, Texas (3097-331) U.S. Geological Survey (USGS) 7.5-minute quadrangle map (see Figure 1). The Project is located on the southwest corner at the intersection of Main Street and Patterson Avenue, within the Florence city limits in Williamson County, Texas. The Project area is within an urban setting that is largely commercial and residential development (see Figure 2). Overall, the Project area is approximately 300 -feet-long (north to south), 200-feet-wide (east to west), encompassing about 1.2 acres. The Project is expected to replace the three existing buildings on the property, and the new municipal complex will be built to include the existing Veteran's Memorial. The property is entirely owned by the City of Florence.

\section{Geology}

The underlying geology throughout the Project area consists of early Cretaceous-aged Walnut Clay (Barnes 1992). The Walnut Clay formation consists of clay, limestone, and shale; based on the age and physical properties of this formation, it has low to moderate potential to contain buried archaeological resources. 


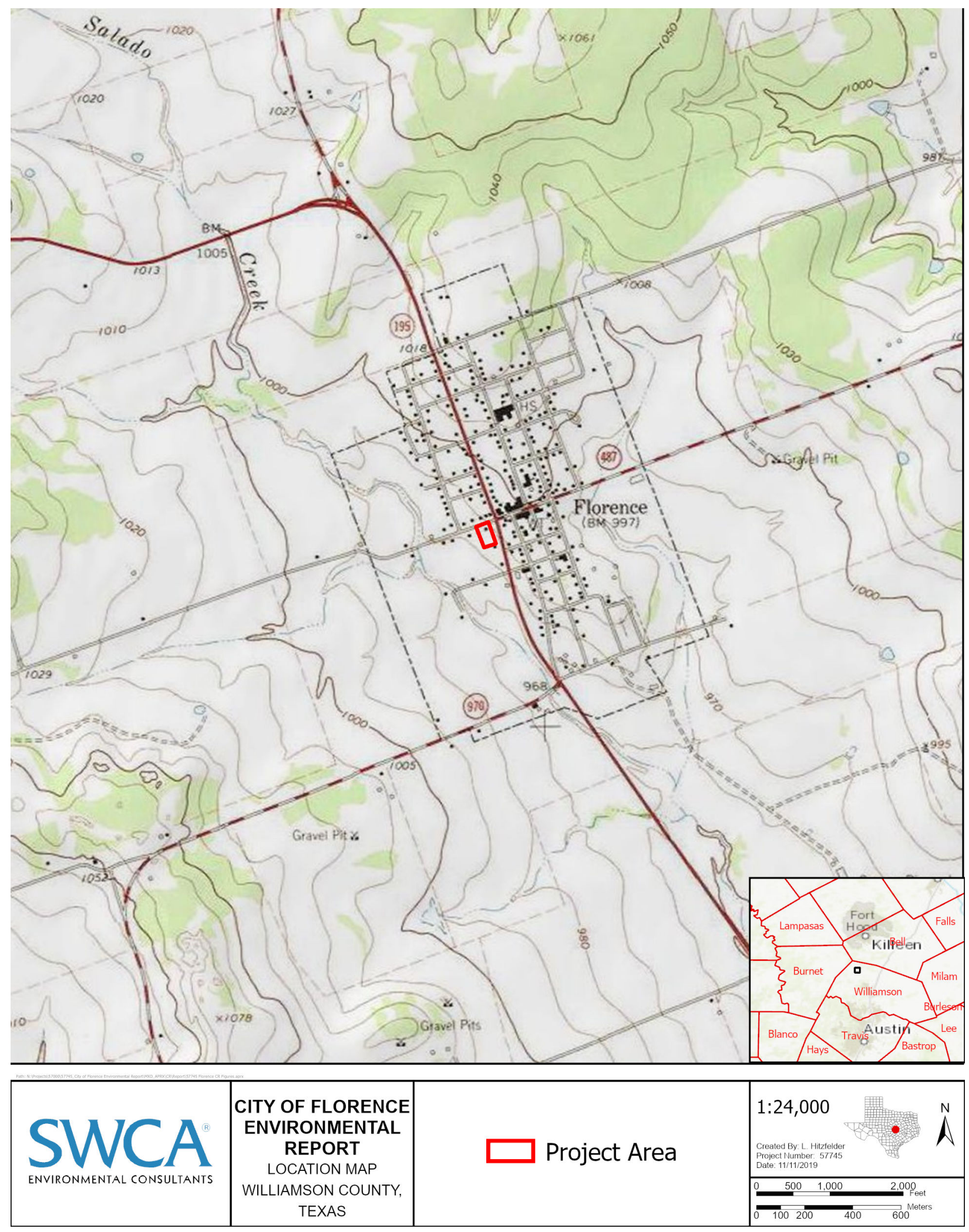

Figure 1. Project area location. 
This page has been removed intentionally to protect sensitive

\author{
cultural materials
}

Figure 2. 


\section{Soils}

The project area is underlain by two soil types; Doss silty clay and Denton silty clay (Figure 3). Doss silty clay (DoC) underlays approximately 92 percent of the total 1.2-acre Project area. The Doss series consists of calcareous loamy to clayey soils derived from marls and limestone, with shallow to weakly cemented limestone interbedded. Denton silty clay (DnB) accounts for approximately 8 percent of the proposed Project area. The Denton series consists of slowly permeable clayey soils over residuum formed from weathering Cretaceous-aged limestone (Natural Resources Conservation Service [NRCS] 2019).

\section{CULTURAL SETTING}

The Project area lies within the Central Texas Region. Although the Texas regions are recent analytical constructs, they do contain a measure of distinct, spatial, cultural information (Collins 2004; Prewitt 1981). Since no prehistoric resources were identified, the focus here is on the historical context. The Historic period begins with the first European documentation from the exploits of Cabeza de Vaca in the 1530s. Further exploration and conquest of Texas by the Spanish occurred, in part, because of accounts of fabled riches suggested by de Vaca and expectations of riches fueled by earlier conquests of Mexico and Peru. The Historic period is divided into eras corresponding to political and social change.

\section{Historic Period}

Landscape features have dictated human movement and subsistence patterns for thousands of years. Specifically, geographical influences during the Historic Period (A.D. 1630-present) confined settlements to riparian zones and limited farming to these areas. The larger rugged landscape was used for sheep, goat, and cattle ranching. These practices were introduced and promoted by the Spanish as part of their colonial agenda, and many were carried through to the twentieth century, giving Texas a strong agricultural history that dominated economic, social, and cultural patterns over the years (Freeman 1994).

Accordingly, the following historic context emphasizes the changes to rural Texas in terms of its agricultural and economic history. These developments, in effect dictated the social and political development of central Texas as seen against the backdrop of broader Texas history in and around the Project area. The beginning of the late seventeenth and early eighteenth centuries was an era of more permanent contact between Europeans and Native Americans as the Spanish moved northward out of Mexico to establish settlements and missions on their northern frontier (see Castañeda [1936-1958] and Bolton [1970] for extended discussions of the mission system and Native relations in Texas and central Texas region). Little information is available on aboriginal groups and their ways of life except for the fragmentary data Spanish missionaries gathered. In central Texas and areas to the south, these groups have been referred to collectively as Coahuiltecans because of an assumed similarity in way of life, but many individual groups may have existed (Campbell 1988). This area also served as a point of contact between the southward-advancing Apaches and the Spanish, with native groups often caught in between. Disease and hostile encounters with Europeans and intruding groups such as the Apache were already wreaking their inevitable and disastrous havoc on native social structures and economic systems by this time. 


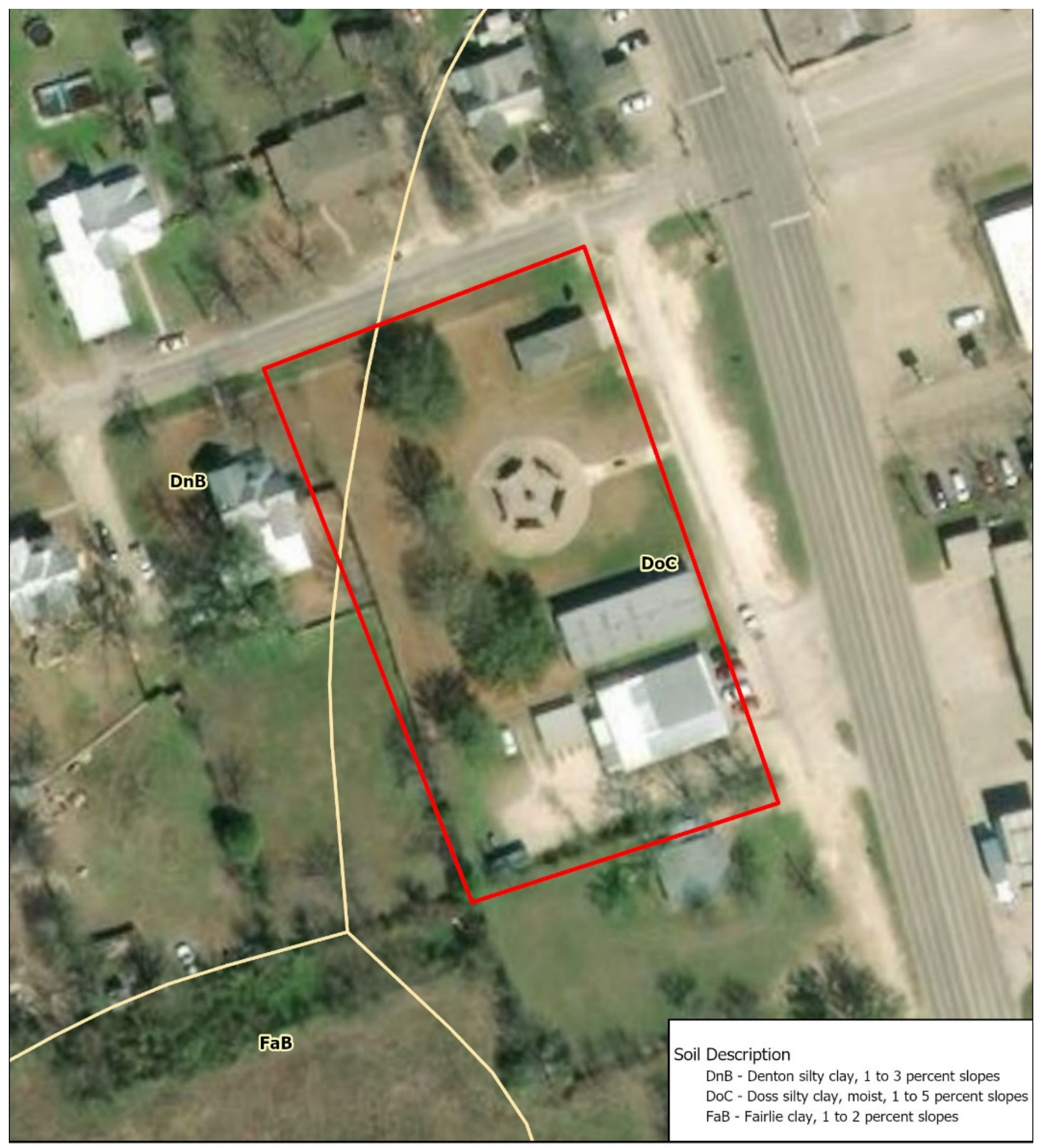

\begin{tabular}{|c|c|c|c|}
\hline & $\begin{array}{c}\text { CITY OF FLORENCE } \\
\text { ENVIRONMENTAL } \\
\text { REPORT } \\
\text { SOIISMAP }\end{array}$ & Project Area & 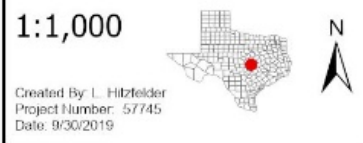 \\
\hline ENVIRONMENTAL CONSULIANIS & $\begin{array}{c}\text { WILLIAMSON COUNTY, } \\
\text { TEXAS }\end{array}$ & & 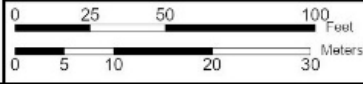 \\
\hline
\end{tabular}

Figure $3 . \quad$ Project area soils map. 


\section{Republic of Texas/Pre-Civil War (1836-1860)}

During the Republic of Texas era, from 1836 to 1845, portions of central Texas remained a Native American stronghold and stayed that way until the 1870s. On December 29, 1845, Congress signed the Texas Admission Act, the result of several years of annexation debate. A few months later, on February 19,1846 , members of the newly formed state government conducted a ceremony in front of the Capitol in Austin marking Texas' official annexation into the Union and the end of the Republic of Texas (Campbell 2003:186; Miller and Faux 1997:78).

\section{The Post-Civil War to Twentieth Century (1865-1950)}

Subsequent to the Civil War, Texas entered the Reconstruction period. To begin Reconstruction, federal troops, in part, had to spread the word of the Emancipation Proclamation (Campbell 2003:268). In Galveston on June 19, 1865, General Gordon Granger and the Union Army spread the word of the slaves' emancipation (Campbell 2003:268). Thus, this day became known as "Juneteenth" and has been celebrated by Texas African Americans since (Campbell 2003:268).

In 1871, the Texas legislature established the Agricultural and Mechanical College of Texas, later to become Texas A\&M University. The first public institution of higher education in the state, the college held its first classes in 1876. Prior to World War I, the Texas legislature further authorized establishment of the School of Veterinary Medicine.

Recovery during the late nineteenth century was gradual but was assisted by a diverse agricultural economy, particularly cattle ranching. In the 1870 s, several major cattle trails heading to markets passed through central Texas. One invention that influenced Texas and its economy during this time was barbed wire. Barbed wire, first demonstrated in 1871, enabled ranchers to shift land and cattle control to a lessintrusive, more profitable plan, and brought additional commerce and trade to central and south Texas (NRHP 1976). Although barbed wire was one of the largest influences on Texas in general, the "invention" with the most influence on the region was the railroad. The railroads served as a means of transportation and generally bolstered growth in the economies, to varying degrees, of the region. For Texas A\&M, the railroad offered a major means of transport to and from the newly established campus, and the College Station depot became the namesake for the city that grew around the university.

Throughout the early twentieth century, trade, transportation, and tourism continued to bring economic prosperity to the region. The establishment of military facilities (e.g., Fort Sam Houston) and the activity surrounding World War I and World War II kept the railway system active, and commercial activity in eastern Texas prospered.

Throughout the remainder of the twentieth century, the population in central Texas increased, largely because of expansion of and commercial opportunities in urban and rural areas. The construction of public highways and advent of automobiles allowed central Texas citizens to commute to urban employment. 


\section{Local History}

The City of Florence, Texas, was founded in the early 1850s. The original community was named Brooksville; however, the name was quickly changed to Florence by 1857 . The town flourished during the Reconstruction Era, the principal industry being cattle and other agriculture. By the turn of the century, the Florence city limits contained a college, several stores, a hotel, and a cheese factory. The population of the town peaked with approximately 1,000 residents between 1927 and 1929. However, the town population dramatically dropped during the Great Depression and did not exceed 1,000 residents again until the 1990 census was taken (Texas State Historical Association 2019).

\section{BACKGROUND AND HISTORICAL MAP REVIEW}

SWCA performed a cultural resources desktop review, including a background and historical map review, on September 27, 2019. To conduct the background review, an SWCA archaeologist reviewed the Florence, Texas, USGS 7.5-minute quadrangle map on the Texas Archeological Sites Atlas (Atlas), the THC's cultural resources database (THC 2019). This source provided information on the nature and location of previously conducted cultural resources investigations, previously recorded archaeological sites, locations of NRHP districts and properties, sites designated as SALs, Official Texas Historical Markers, Recorded Texas Historic Landmarks, cemeteries, and local neighborhood surveys. However, the Atlas does not necessarily list all previous work conducted within a specific area. Previous cultural resources investigations listed on the Atlas are typically limited to projects under purview of the ACT or NHPA. In addition, projects under these regulations may not be posted on Atlas due to a delay between the completion of fieldwork and the completion of reports.

As part of the historical map review, an SWCA archaeologist reviewed the Texas Department of Transportation Historic Overlay, a mapping/geographic information system (GIS) database with historical maps and resource information covering most portions of the state (Foster et al. 2006). The archaeologist also reviewed USGS historical topographic maps available on the USGS TopoView website (USGS 2019). Furthermore, modern aerial imagery was reviewed to identify land use practices that may indicate the potential for, or presence of, cultural resources within the Project area. SWCA reviewed these resources to identify possible historic resources and potential historical structures.

The background and historical map review focused on the Project area, and a 1-mile (1.6-km) buffer around the Project area (i.e., review area). The background literature review determined that no cultural resources surveys have been conducted within the proposed Project area and that no prehistoric or historic resources have been recorded within the Project area. Two archaeological sites (i.e., 41WM1274 and 41WM1230), two cemeteries (i.e., Florence Cemetery and Tomlinson Cemetery), and three historical markers (i.e., marker numbers 14355, 12417, and 9084) are located within 1 mile of the Project area (Figure 4) (THC 2019). The historic map review also revealed 24 potentially historic-age structures adjacent to (within 350 feet of) the current Project area, two of which potentially intersect with the Project (Figure 5) (USGS 2019). The cultural resources desktop review results are further discussed in the following sections. 


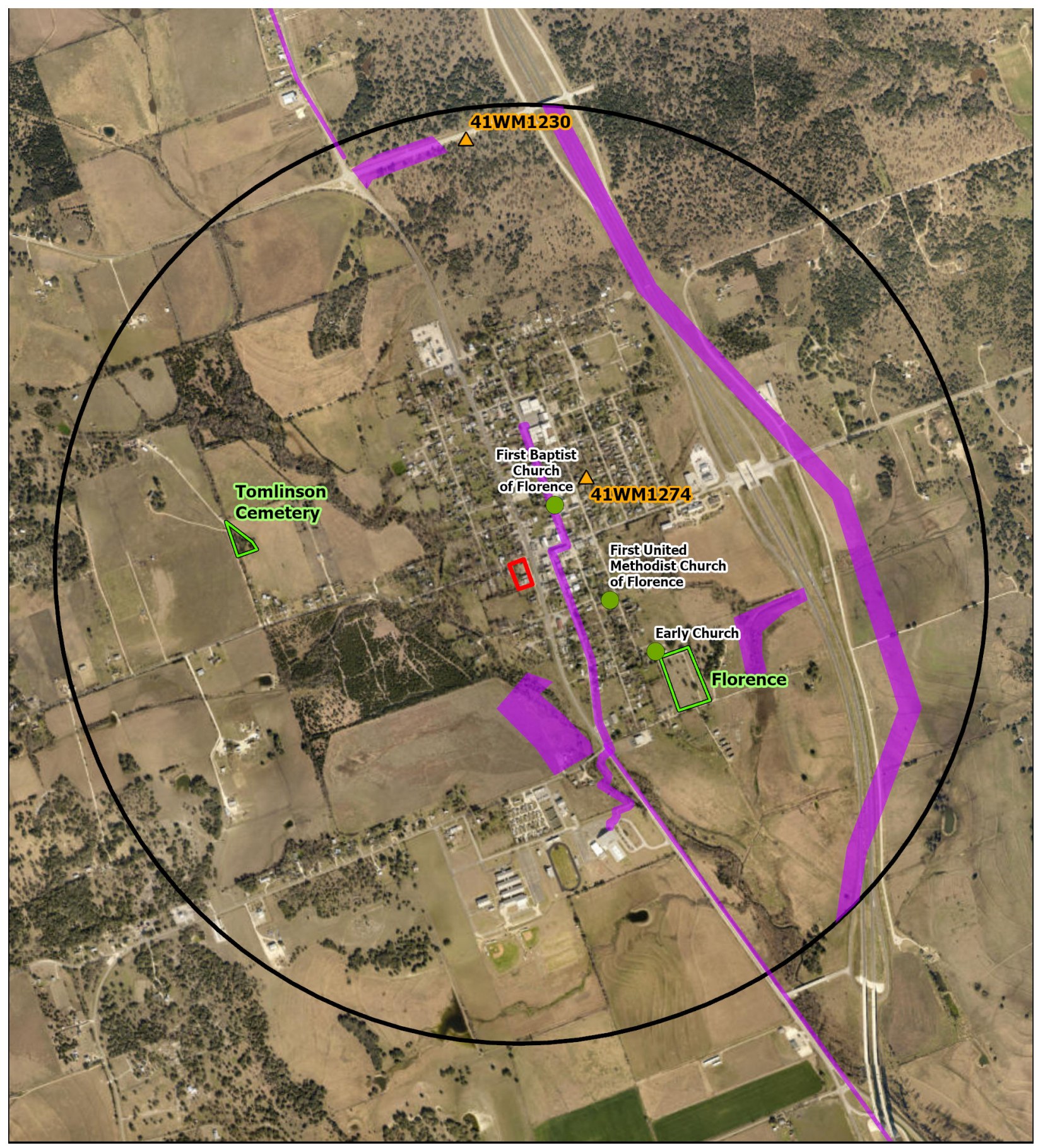

\begin{tabular}{|c|c|c|c|}
\hline & $\begin{array}{l}\text { CITY OF FLORENCE } \\
\text { ENVIRONMENTAL } \\
\text { REPORT } \\
\text { CULTURAL RESOURCES }\end{array}$ & $\begin{array}{l}\square \text { Project Area } \\
\text { 1-mile Review Area } \\
\triangle \text { Previously Recorded Site } \\
\quad \text { Previous Linear Archaeological Survey }\end{array}$ & 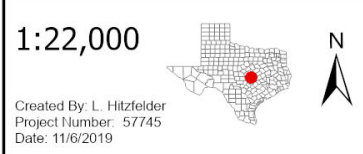 \\
\hline & $\begin{array}{l}\text { BACKGROUND REVIEW MAP } \\
\text { WILLIAMSON COUNTY, } \\
\text { TEXAS }\end{array}$ & $\begin{array}{l}\text { Previous Archaeological Survey Area } \\
\text { Historical Markers }\end{array}$ & 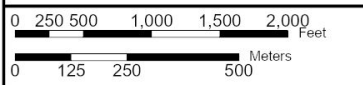 \\
\hline
\end{tabular}

\section{Figure 4. Background review results map.}




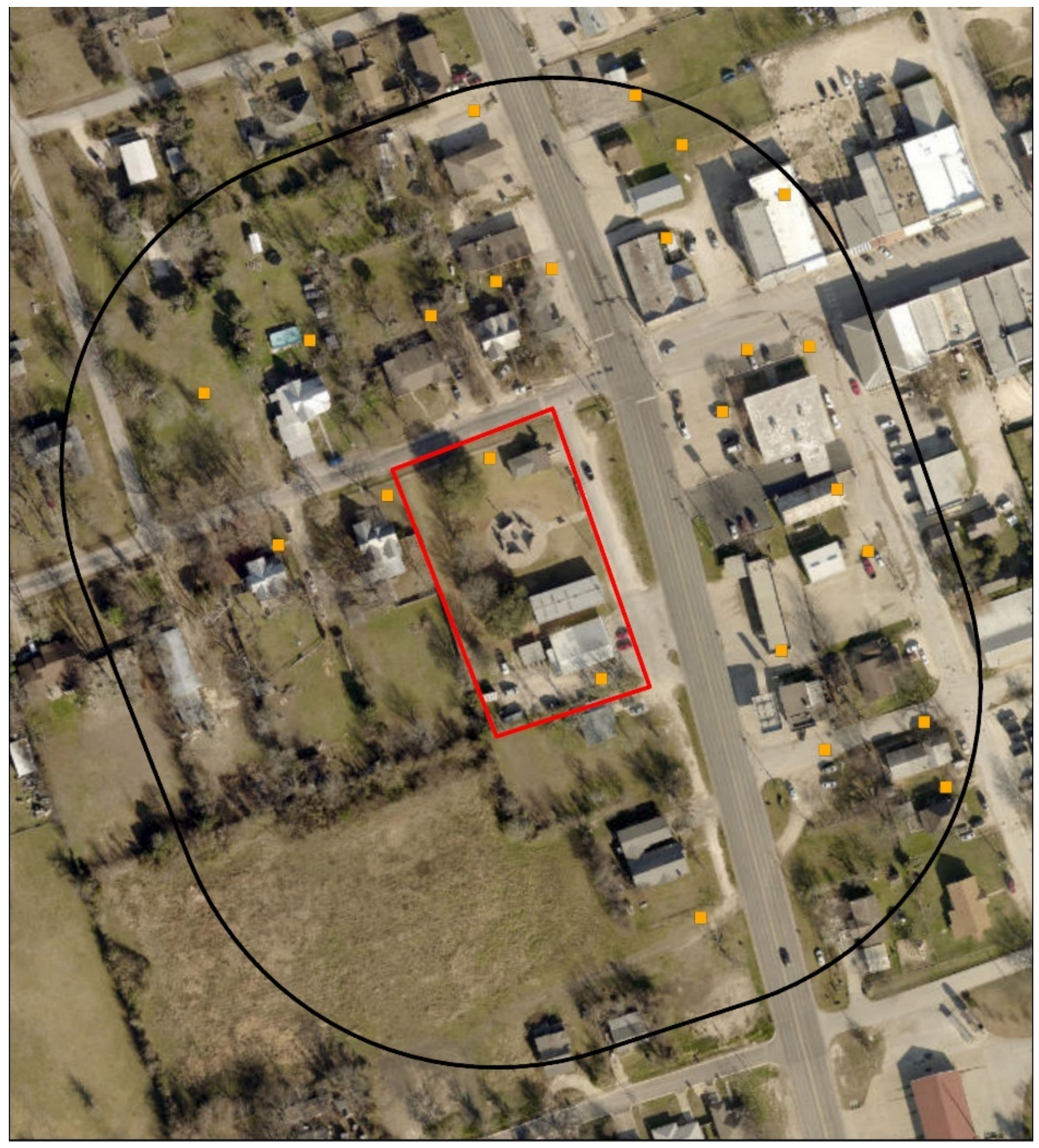

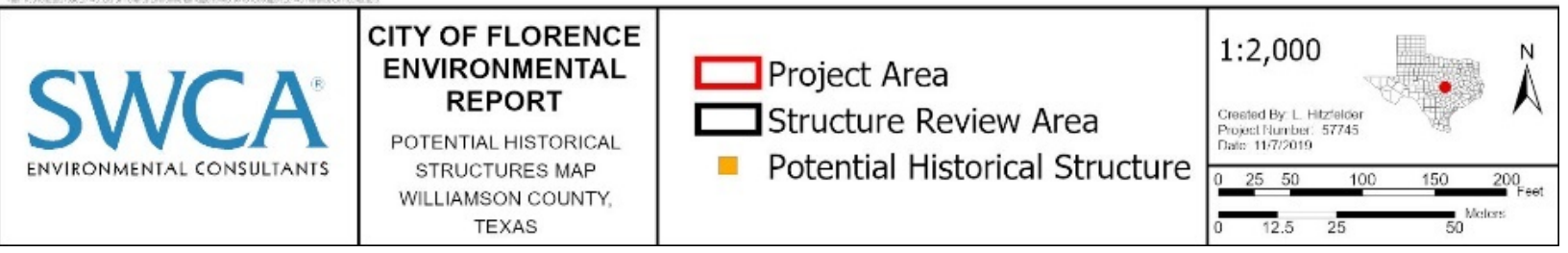

Figure 5. Potential historical structures map. 


\section{Previously Recorded Archaeological Sites}

Archaeological site 41WM1274 is located approximately 0.23 mile from the Project area and was originally recorded in 2013 (see Figure 4). The site is described as a standing, historic-age municipal jail, which was likely built in the early twentieth century (THC 2019). The NRHP eligibility was not assessed during the initial recordation and the THC has not decided on NRHP or SAL eligibility.

Archaeological site 41WM1230 is located approximately 0.94 mile from the Project area and was originally recorded in 2009. The site is described as a small lithic procurement site (THC 2019). The recording archaeologist recommended the site as not eligible for the NRHP or as an SAL, and the THC has not made a determination as to NRHP or SAL eligibility.

\section{Cemeteries}

As noted, the background review identified two cemeteries within the review area (see Figure 4). The Florence Cemetery is located approximately 0.33 mile southeast of the Project. This cemetery identification number is WM-C061 and it is recorded as containing 2,040 interments that date from the late 1800s to the present (THC 2019; Find a Grave 2019). The Tomlinson Cemetery is located approximately 0.56 mile west of the Project area. The cemetery identification number is WM-C128; however, information on the number and dates of interments could not be obtained (THC 2019). The Florence and the Tomlinson Cemeteries will not be affected by the proposed Project.

\section{Historical Markers and Historic Map Review}

The background review determined that three historical markers (i.e., marker numbers 14355, 12417, and 5638) are within 1 mile of the Project area (see Figure 4). Historical marker number 14355 is located approximately 0.18 mile southeast of the Project area and commemorates the First United Methodist Church of Florence and was erected in 2002 (THC 2019). Historical marker number 12417 is located approximately 0.14 mile northeast from the Project area and commemorates the First Baptist Church of Florence, established in 1856. The marker for the Baptist Church was erected in 2001 (THC 2019). Finally, historical marker number 9084 is located approximately 0.32 mile southeast from the Project area and commemorates the Early Church in Florence. The Early Church is thought to have been erected in 1855, and the state marker was erected in 1970 (THC 2019). Finally, the historic map review revealed 24 possible historic-age structures adjacent (within 350 feet) to the Project area (see Figure 5) (USGS 2019). These structures are depicted on the 1964 and 1966 Florence, Texas, USGS topographic quadrangle maps; two of the structures appear to be potentially located within the Project area.

\section{FIELD SURVEY METHODS}

The goal of the investigation was to locate all prehistoric and historic cultural resources within the Project area, establish vertical and horizontal site boundaries as appropriate within the Project area, and recommend NRHP and SAL eligibility of any cultural resources located within the Project area. This investigation followed the guidelines and procedures outlined in the CTA standards for cultural resources investigations and the ACT, as outlined in the THC's Rules of Practice and Procedure for the Antiquities Code of Texas. For project areas 0-2 acres in size, the THC/CTA survey standards require a minimum of three shovel test per acre, which equates to minimally four shovel tests across the Project area. Additional shovel testing may be required to delineate cultural resources. Factors such as disturbances, site probability, and exposures may also affect shovel testing intensity. 
The intensive pedestrian survey consisted of a qualified SWCA archaeologist walking and inspecting the Project area using a series of parallel 100 -foot-wide $(30-\mathrm{m})$ transects. The survey examined the ground surface for cultural material and features, documented features of the landscape, documented modifications and disturbances in the area, and used shovel tests and erosional exposures to assess the potential for subsurface archaeological deposits. Shovel tests were excavated in areas that did not show signs of extensive prior disturbance, consisted of soils believed to have a potential for buried deposits close enough to the surface to be detected through this method of subsurface investigation, and had less than 30 percent ground surface visibility. Shovel tests were excavated in $20-\mathrm{cm}$ arbitrary levels to a depth of 1 meter, unless soil conditions or argillic horizon precluded reaching that depth. All matrix was screened through $1 / 4$-inch mesh for artifact recovery. SWCA plotted each shovel test location using a sub-meter accurate global positioning system (GPS) receiver and recorded each test on appropriate field forms during survey investigations.

All survey-related documentation will be curated at the Center for Archaeological Studies, Texas State University, San Marcos, Texas. SWCA will furnish the THC and the Texas State Library and Archives Commission and the State Publications Depository Program each with one printed copy of the final report. SWCA will also provide 11 printed copies of the final report for distribution without site location information to university-based libraries and archaeological research facilities around the state.

\section{FIELD SURVEY RESULTS}

SWCA conducted an intensive archaeological survey of the Project area on November 5, 2019. The survey included ground surface inspection augmented with shovel testing and the inspection of any available surface exposures. SWCA assessed the City of Florence's proposed Municipal Facilities Complex parcel and confirmed that none of the four extant buildings/structures within the Project area, can be considered to be historic (i.e., 50 years or older). The four buildings/structures within the Project area include the Florence City Hall, a thrift store, a large Veteran's Memorial, and the Florence Chamber of Commerce (Figure 6). These structures are discussed in greater detail below.

Substantial modifications to the landscape have occurred within and adjacent to the Project area on all sides from years of town development and associated infrastructure. Land use has been consistent over the last several decades, with widespread surficial disturbances associated with building and structure construction, parking lot construction, and road construction, as well as deeper impacts associated with foundations, buried utilities, landscaping and tree planting, and a sprinkler system (Figure 7).

Subsurface examination of the Project area involved the excavation of 12 shovel tests (i.e., EMA001EMA012) (Table 1; Figure 8). The investigation far exceeded the THC's standards for shovel testing for projects of this size. Shovel tests typically contained grayish brown (10YR 5/2) to brown (10YR 5/3) silty loam with a moderate to high gravel content ranging from 5 percent to greater than 30 percent, overlying a dark grayish brown (10YR 4/2) clay loam. Shovel tests extended to a maximum depth of approximately $50 \mathrm{~cm}$ below the surface (cmbs) and terminated upon encountering impassable gravels, compact soils, or significant disturbances which may have indicated a buried utility. Most of the shovel tests exhibited evidence of heavily disturbed soils and/or imported fill gravels. Of the 12 shovel tests excavated, three proved positive for subsurface cultural materials. The three positive shovel tests constitute an isolated find (i.e., IF01), which is described in further detail below. 

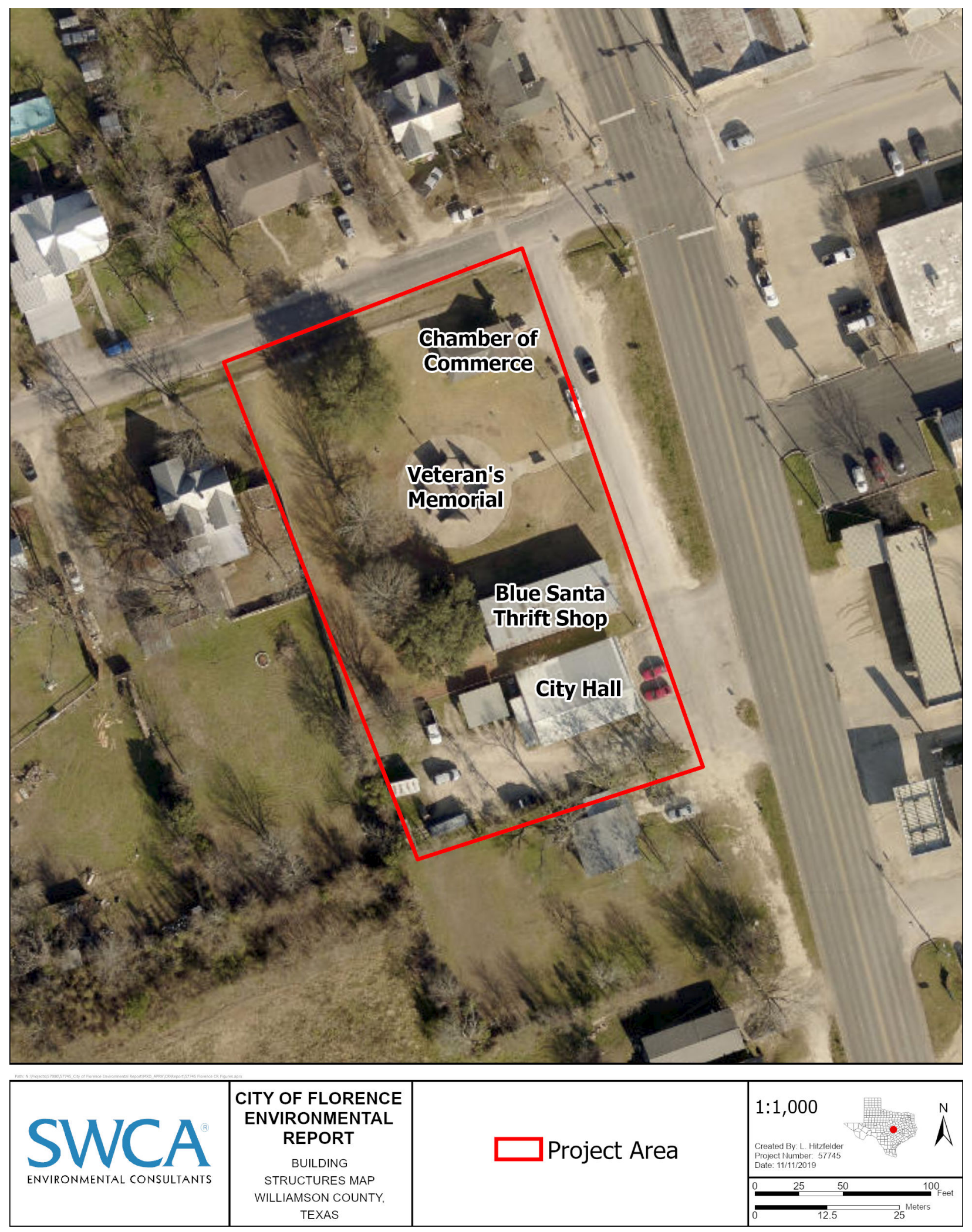

Figure 6. Buildings/Structures within the Project area. 


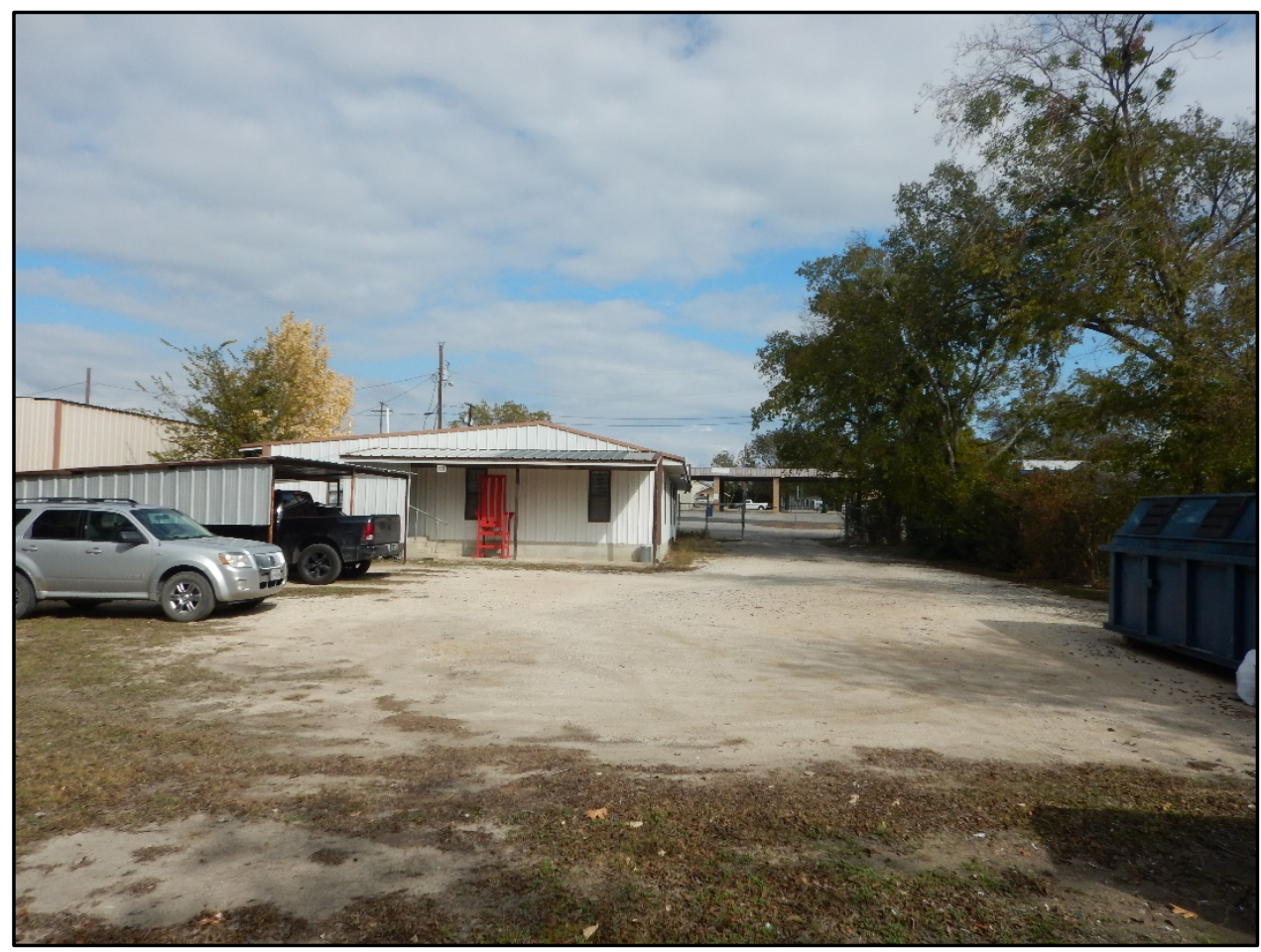

Figure 7. Example of extensive soil disturbance due to building, foundation, and parking lot construction.

\section{IF01}

Isolated find 1 (IF01) comprises three adjacent shovel tests that contained modern cultural materials and constitute the only subsurface cultural resource within the Project area (see Figures 8 and 9). Shovel test EMA006 uncovered a metal axe head between 10 and $20 \mathrm{cmbs}$ and an unidentifiable metal fragment from approximately 30 to $40 \mathrm{cmbs}$ (Figure 10). The axe head is of a common design and is not diagnostic to a particular date range. Shovel test EMA007 encountered a white-bodied earthenware ceramic sherd between approximately 25 and $35 \mathrm{cmbs}$ (Figure 11). The sherd does not exhibit diagnostic characteristics, which could provide a date range. The sherd is undecorated, has some crazing and soil staining of the glaze, but does not appear to have been buried beneath the surface for a long period of time. Shovel test EMA009 encountered a round, rusted nail between 20 and $30 \mathrm{cmbs}$ (Figure 12). The nail being round is the only discernable characteristic, as it has been distorted by oxidation. Finally, a broken modern, plastic sprinkler head was found at the same depth as the nail and could indicate the nail is of a modern origin, or the soil has been severely disturbed (see Figure 12).

After evaluating the material and the Project area, SWCA concludes IF01 does not warrant elevation to archaeological site status for several reasons. First, the materials uncovered in the shovel tests lack diagnostic features and cannot be accurately attributed to the historic period (i.e., 50 years old or greater). Further, there is an abundance of evidence for significant soil disturbance throughout the project area. Decades of construction, combined with landscaping and buried utilities, has left very little of the substrate intact. The lack of original soil integrity diminishes the ability to determine original artifact provenience, as well as context. As evidence of either the lack of soil integrity, or the modernity of the recovered material, modern plastic fragments were found with the round, rusty nail at near the same level as the other recovered materials (i.e., 20 to $30 \mathrm{cmbs}$ ). Due to these reasons, SWCA concludes the three positive shovel tests combine to constitute an isolated find and do not warrant elevation to archaeological site status. 
Table 1. Shovel Test Data

\begin{tabular}{|c|c|c|c|c|c|c|c|}
\hline $\begin{array}{l}\text { Shovel } \\
\text { Test No. }\end{array}$ & Level & $\begin{array}{l}\text { Depth } \\
\text { (cmbs) }\end{array}$ & $\begin{array}{l}\text { Munsell } \\
\text { Value }\end{array}$ & $\begin{array}{l}\text { Munsell } \\
\text { Color }\end{array}$ & Texture & Inclusions & $\begin{array}{l}\text { Comments I } \\
\text { Reason for Termination }\end{array}$ \\
\hline EMA001 & 1 & $0-35$ & 10YR 5/2 & $\begin{array}{l}\text { Grayish } \\
\text { brown }\end{array}$ & Silty loam & $\begin{array}{l}10 \% \\
\text { roots/rootlets, } \\
5 \% \text { gravels }\end{array}$ & $\begin{array}{l}\text { No cultural material encountered. } \\
\text { Terminated due to heavily } \\
\text { disturbed soil. }\end{array}$ \\
\hline EMA002 & 1 & $0-12$ & 10YR 5/2 & $\begin{array}{l}\text { Grayish } \\
\text { brown }\end{array}$ & Silty loam & $\begin{array}{l}10 \% \\
\text { roots/rootlets, } \\
40 \% \text { gravels }\end{array}$ & $\begin{array}{l}\text { No cultural material encountered. } \\
\text { Terminated due to disturbance } \\
\text { from the sprinkler system. }\end{array}$ \\
\hline EMA003 & 1 & $0-35$ & 10YR 5/2 & $\begin{array}{l}\text { Grayish } \\
\text { brown }\end{array}$ & Silty loam & $\begin{array}{l}5 \% \\
\text { roots/rootlets, }\end{array}$ & $\begin{array}{l}\text { No cultural material encountered. } \\
\text { Terminated due to heavily } \\
\text { disturbed soil. }\end{array}$ \\
\hline EMA004 & 1 & $0-18$ & 10YR 5/2 & $\begin{array}{l}\text { Grayish } \\
\text { brown }\end{array}$ & Silty loam & $\begin{array}{l}25 \% \\
\text { roots/rootlets, } \\
35 \% \text { gravels }\end{array}$ & $\begin{array}{l}\text { No cultural material encountered. } \\
\text { Terminated due to heavily } \\
\text { disturbed soil. }\end{array}$ \\
\hline \multirow[t]{2}{*}{ EMA005 } & 1 & $0-15$ & 10YR $5 / 3$ & brown & Silty loam & $\begin{array}{l}30 \% \\
\text { roots/rootlets, }\end{array}$ & No cultural material encountered. \\
\hline & 2 & $15-35$ & 10YR $4 / 2$ & $\begin{array}{l}\text { Dark grayish } \\
\text { brown }\end{array}$ & $\begin{array}{l}\text { Clay } \\
\text { loam }\end{array}$ & $20 \% \mathrm{CaCO} 3$ & $\begin{array}{l}\text { No cultural material encountered. } \\
\text { Terminated due to a heavy } \\
\text { concentration of calcium } \\
\text { carbonate. }\end{array}$ \\
\hline \multirow[t]{2}{*}{ EMA006 } & 1 & $0-15$ & 10YR $5 / 3$ & Brown & Silty loam & $\begin{array}{l}20 \% \\
\text { roots/rootlets, }\end{array}$ & $\begin{array}{l}\text { A metal axe head was found } \\
\text { between } 10 \text { and } 20 \mathrm{cmbs} \text {. }\end{array}$ \\
\hline & 2 & $15-50$ & 10YR 4/2 & $\begin{array}{l}\text { Dark grayish } \\
\text { brown }\end{array}$ & $\begin{array}{l}\text { Clay } \\
\text { loam }\end{array}$ & - & $\begin{array}{l}\text { An unidentifiable metal fragment } \\
\text { was found between } 30 \text { and } 40 \\
\text { cmbs. Terminated due to } \\
\text { compact soil. }\end{array}$ \\
\hline EMA007 & 1 & $0-35$ & 10YR $5 / 3$ & Brown & $\begin{array}{l}\text { Clay } \\
\text { loam }\end{array}$ & $\begin{array}{l}5-10 \% \\
\text { roots/rootlets, } \\
35 \% \text { gravels }\end{array}$ & $\begin{array}{l}\text { One whiteware sherd was found } \\
\text { between } 25 \text { and } 35 \mathrm{cmbs} \text {. } \\
\text { Terminated due to compact soil. }\end{array}$ \\
\hline EMA008 & 1 & $0-5$ & 10YR $5 / 2$ & $\begin{array}{l}\text { Grayish } \\
\text { brown }\end{array}$ & Loam & $80 \%$ gravels & $\begin{array}{l}\text { No cultural material encountered. } \\
\text { Terminated at dense gravel fill. }\end{array}$ \\
\hline \multirow[t]{2}{*}{ EMA009 } & 1 & $0-30$ & 10YR $5 / 3$ & Brown & Silty loam & $\begin{array}{l}15 \% \\
\text { roots/rootlets, }\end{array}$ & $\begin{array}{l}\text { A round metal nail and modern } \\
\text { plastic fragments were found } \\
\text { between } 20 \text { and } 30 \mathrm{cmbs} \text {. }\end{array}$ \\
\hline & 2 & $30-52$ & 10YR 6/2 & $\begin{array}{l}\text { Light } \\
\text { brownish } \\
\text { gray }\end{array}$ & $\begin{array}{l}\text { Clay } \\
\text { loam }\end{array}$ & - & Terminated at compact soil. \\
\hline EMA010 & 1 & $0-20$ & 10YR $5 / 2$ & $\begin{array}{l}\text { Grayish } \\
\text { brown }\end{array}$ & Silty loam & $\begin{array}{l}10 \% \\
\text { roots/rootlets, } \\
50 \% \text { gravels }\end{array}$ & $\begin{array}{l}\text { No cultural material encountered. } \\
\text { Terminated at bedrock. }\end{array}$ \\
\hline EMA011 & 1 & $0-30$ & 10YR 5/3 & brown & Silty loam & $\begin{array}{l}30 \% \\
\text { roots/rootlets, } \\
30 \% \text { gravels }\end{array}$ & $\begin{array}{l}\text { No cultural material encountered. } \\
\text { Terminated at bedrock. }\end{array}$ \\
\hline \multirow[t]{2}{*}{ EMA012 } & 1 & $0-15$ & 10YR $5 / 3$ & $\begin{array}{l}\text { Grayish } \\
\text { brown }\end{array}$ & Silty loam & $\begin{array}{l}40 \% \\
\text { roots/rootlets, }\end{array}$ & No cultural material encountered. \\
\hline & 2 & $15-40$ & 10YR $3 / 2$ & brown & $\begin{array}{l}\text { Clay } \\
\text { loam }\end{array}$ & - & $\begin{array}{l}\text { No cultural material encountered. } \\
\text { Terminated due to compact soil. }\end{array}$ \\
\hline
\end{tabular}




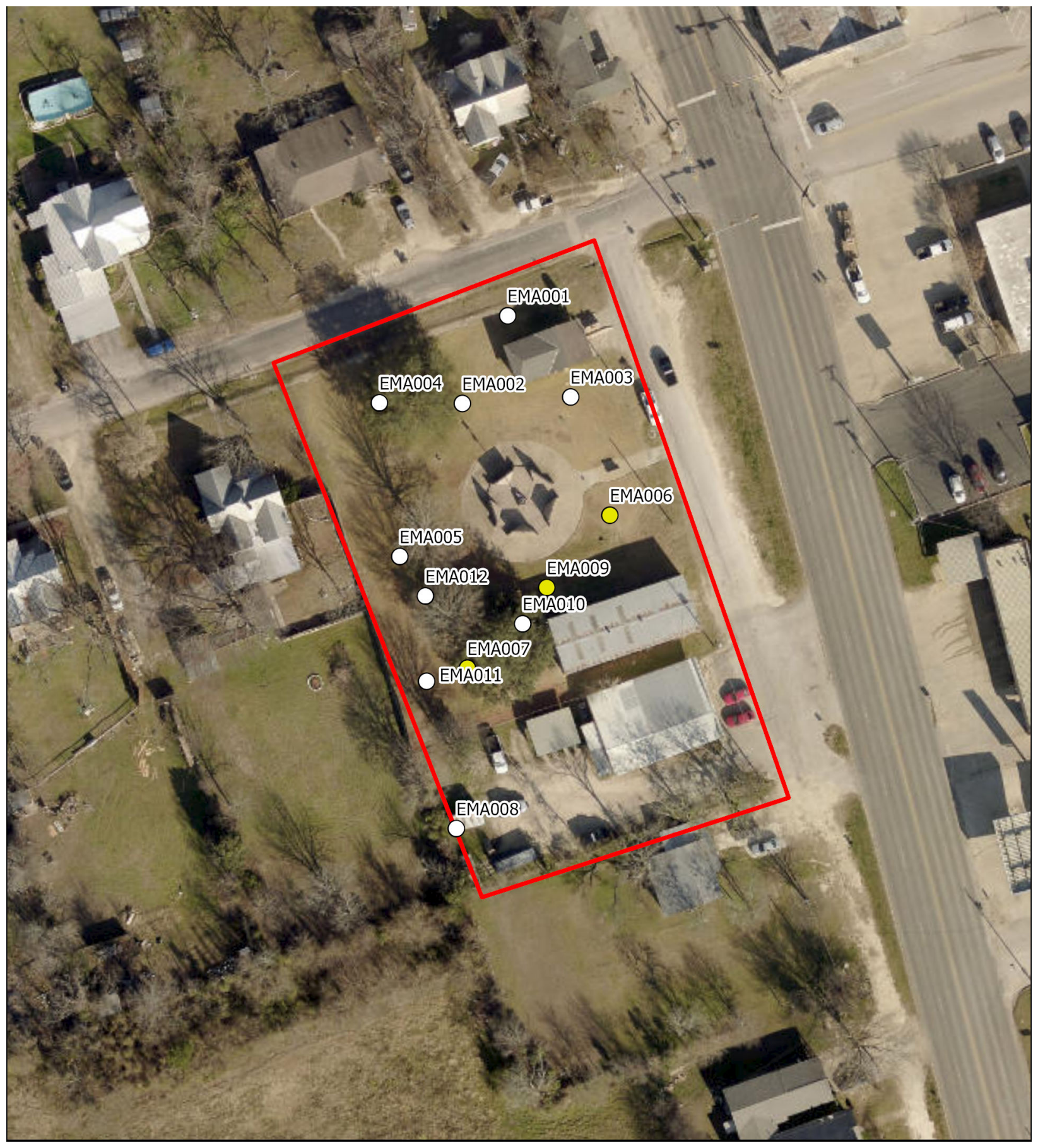

\begin{tabular}{|c|c|c|c|c|}
\hline & $\begin{array}{c}\text { CITY OF FLORENCE } \\
\text { ENVIRONMENTAL } \\
\text { REPORT } \\
\text { CULTURAL RESOURCES }\end{array}$ & 0 & $\begin{array}{l}\text { Project Area } \\
\text { Negative Shovel Test }\end{array}$ & 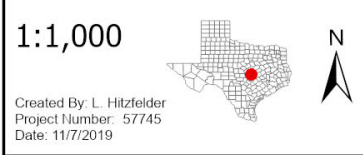 \\
\hline & $\begin{array}{c}\text { SURVEY RESULTS MAP } \\
\text { WILLIAMSON COUNTY, } \\
\text { TEXAS }\end{array}$ & O & Positive Shovel Test & 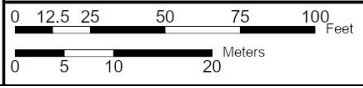 \\
\hline
\end{tabular}

Figure 8. Cultural resources survey results map. 


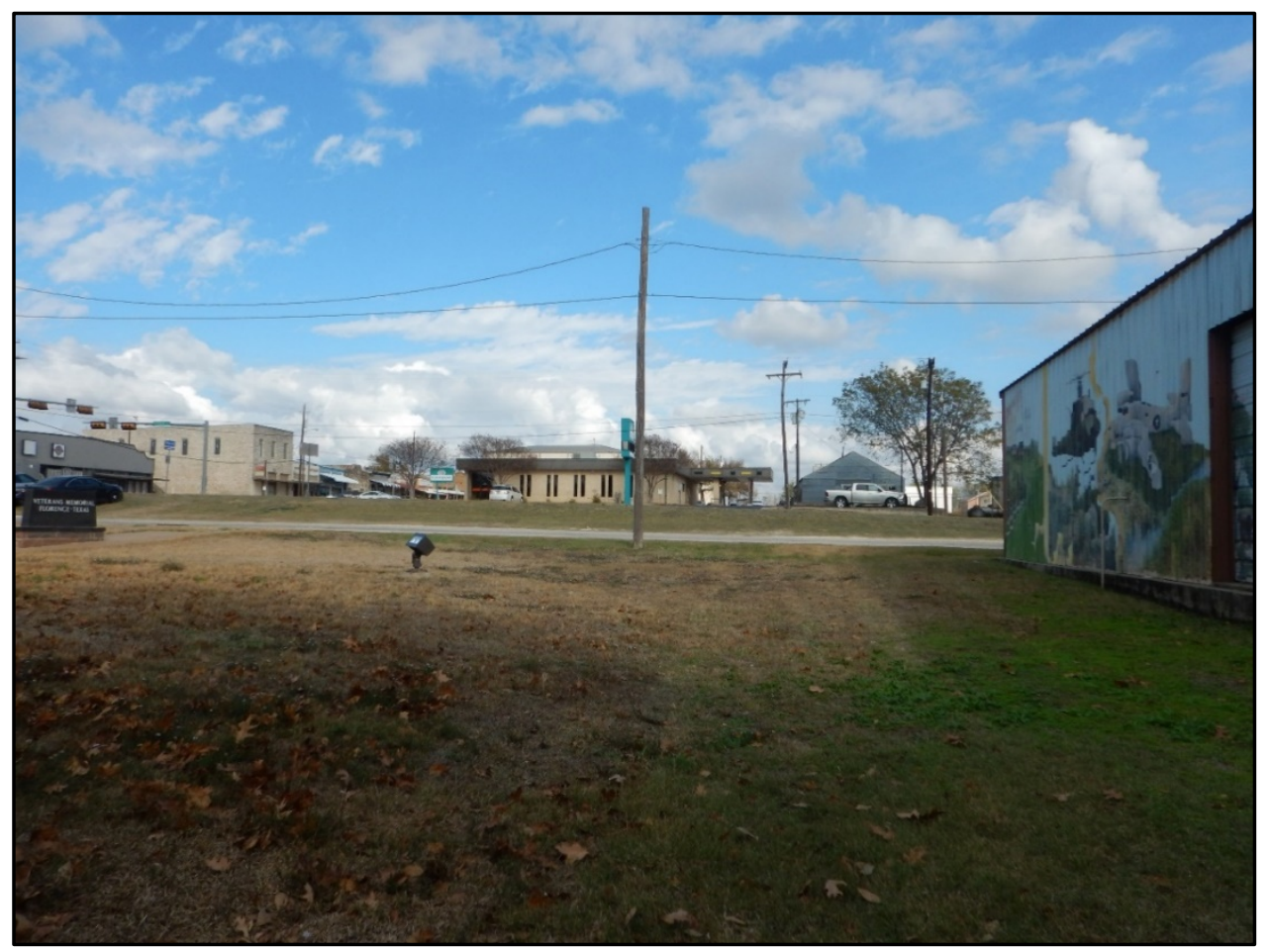

Figure 9. Overview of IF01 location, facing east.

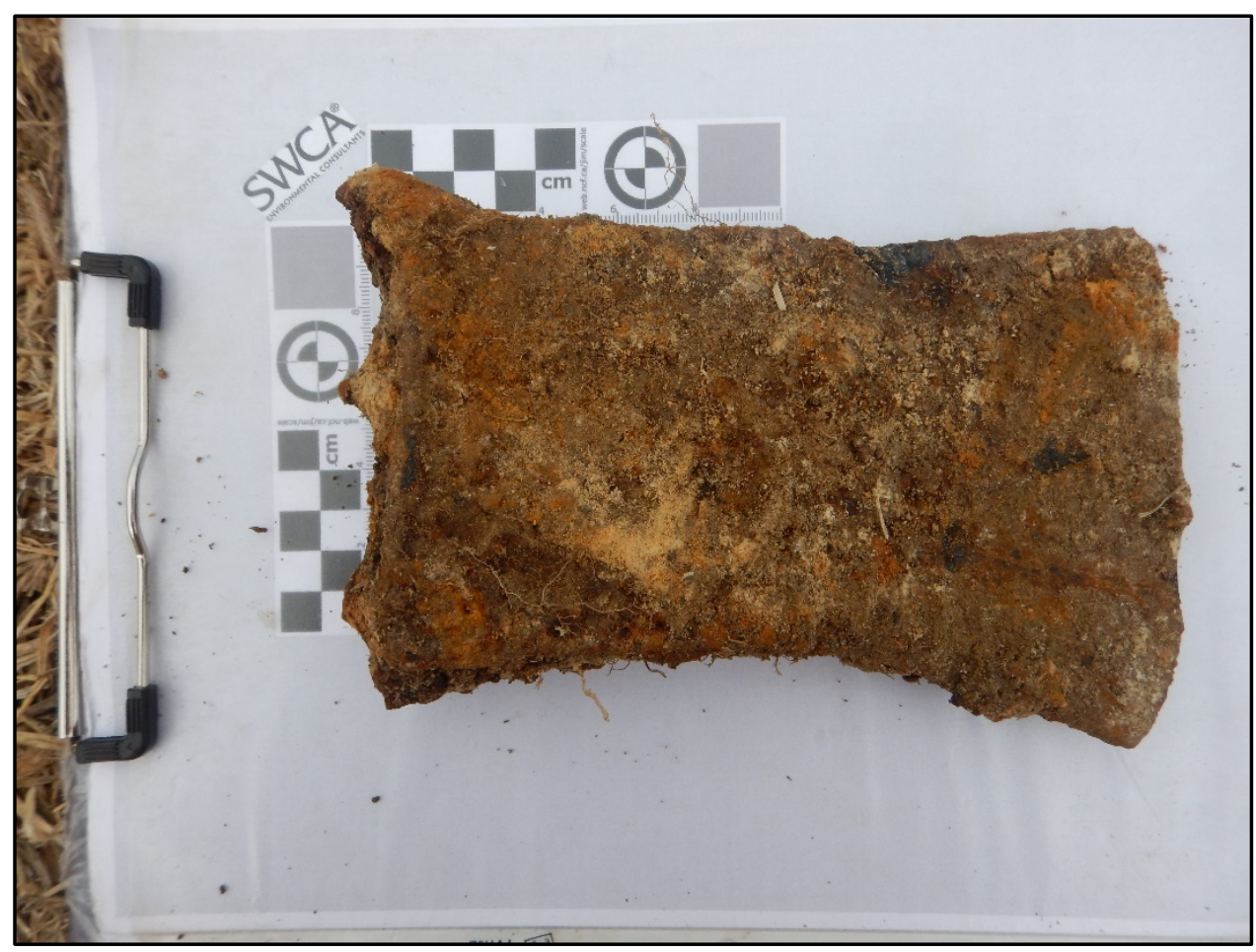

Figure 10. Axe head found in shovel test EMA006. 


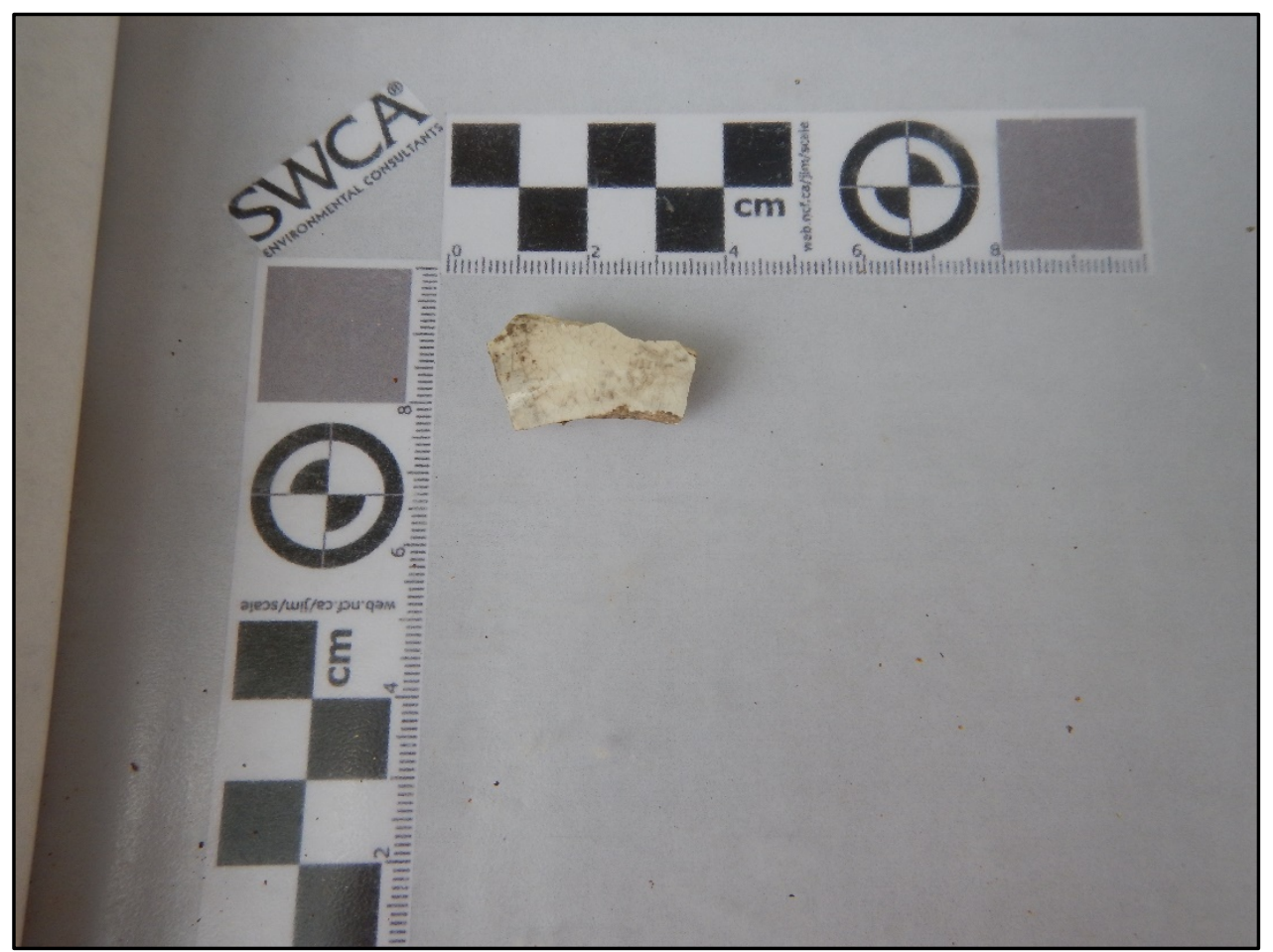

Figure 11. White-bodied earthenware sherd found in shovel test EMA007.

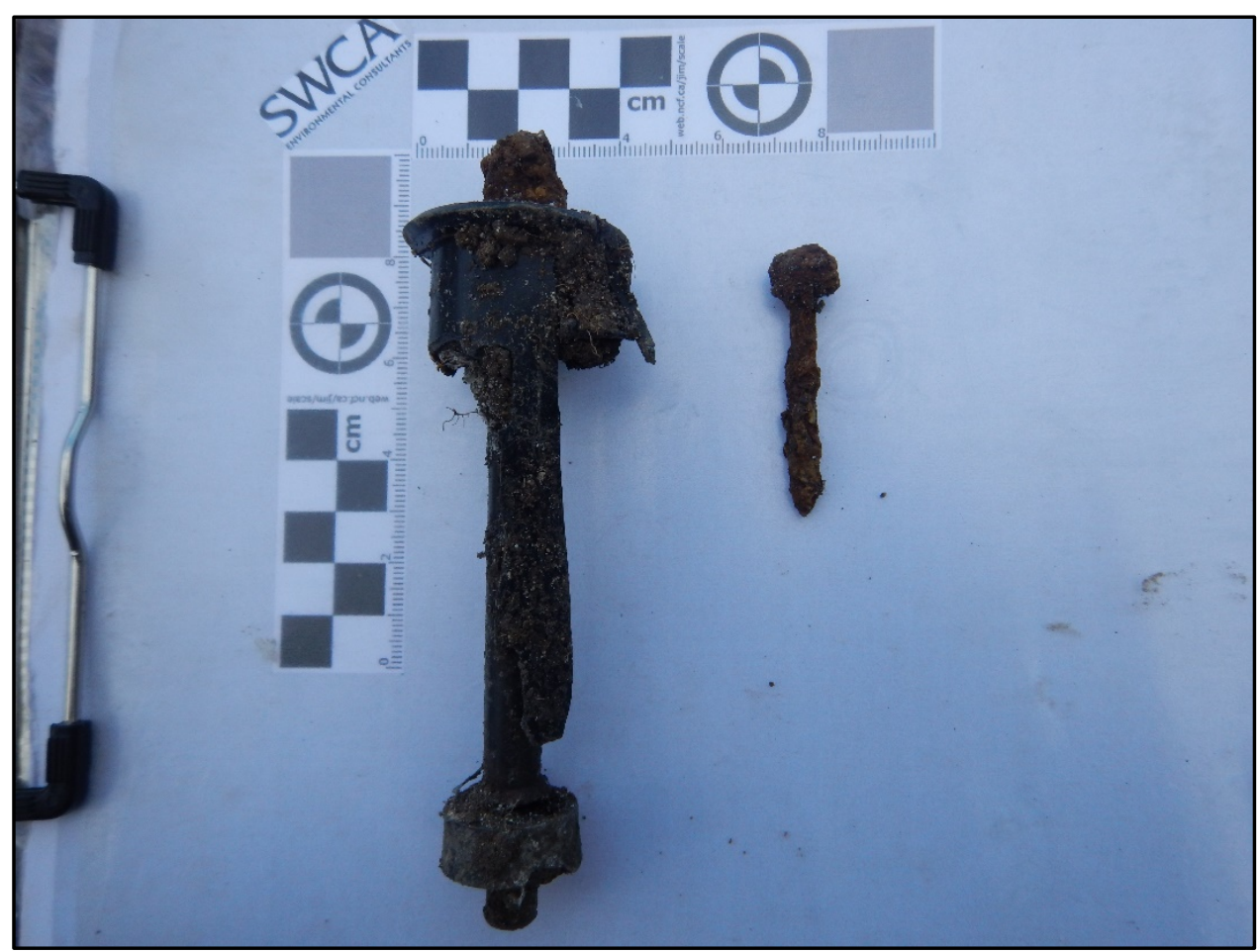

Figure 12. Oxidized nail and modern sprinkler head found together in shovel test EMA009. 


\section{Florence City Hall}

Located at 106 South Patterson Avenue, Florence City Hall is a circa 1980, one-story vernacular building. The rectangular plan building has a corrugated metal, front gable-roof obscured by a front metal awning spanning the full width of the primary elevation (Figure 13). Exterior cladding is corrugated metal, except on the primary elevation, which is stone veneer. The building is at grade on a slab foundation. Windows are 1/1 metal sash units. The primary entry door is recessed and is a modern aluminum and glass unit. Immediately adjacent to City Hall is a metal storage building with rolling garage door and flush metal doors (Figure 14). Like City Hall, its date of construction is circa 1980. Neither structure is eligible for the NRHP.

Immediately adjacent to the proposed site, and within the project area, are the Veteran's Memorial (Figure 15) and the Chamber of Commerce building (Figure 16). The memorial was constructed circa 1990 and historic aerials show no structure in the location of the Chamber of Commerce building until 1981. Based on these investigations, no historic structures remain in the project area. It is also possible that the two potential historic structures noted during the background review could be historic-age residences located immediately adjacent to the project area (Figures 17 and 18); however, neither residence is listed on the NRHP or eligible for listing. Although there are two houses adjacent to the project area, the area is primarily commercial. City Hall is located approximately one block south of Main Street (Figure 19). Although a windshield evaluation determined that there is a core of historic-age buildings along East Main Street, more investigation would be needed to determine if there is an NRHPeligible historic district. Infill of a modern commercial building at the corner of East Main Street and South Patterson Avenue (Figures 20) provides a buffer, so the proposed new City Hall will have no effect on the integrity of any potential historic district designation along the commercial corridor.

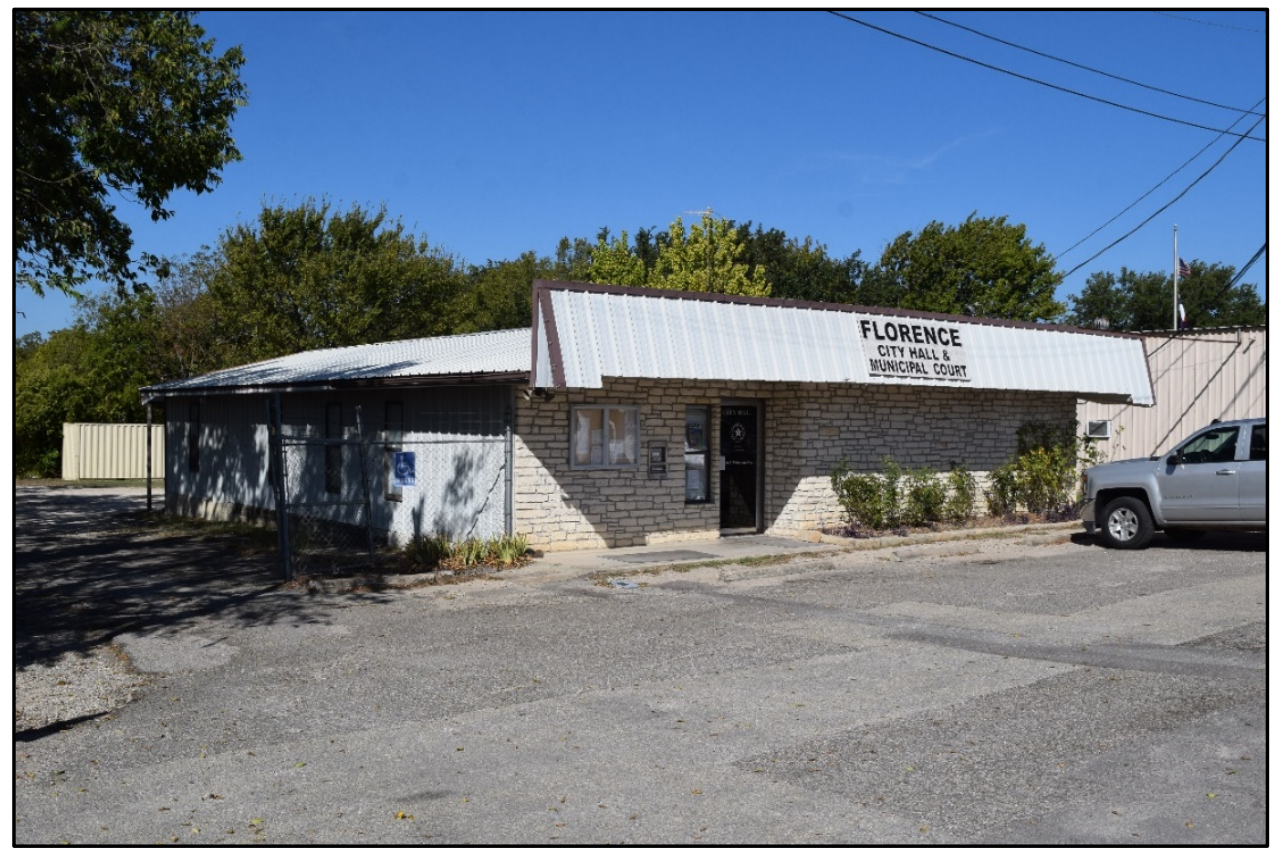

Figure 13. Florence City Hall, oblique, east (front) and south elevations, facing northwest. 


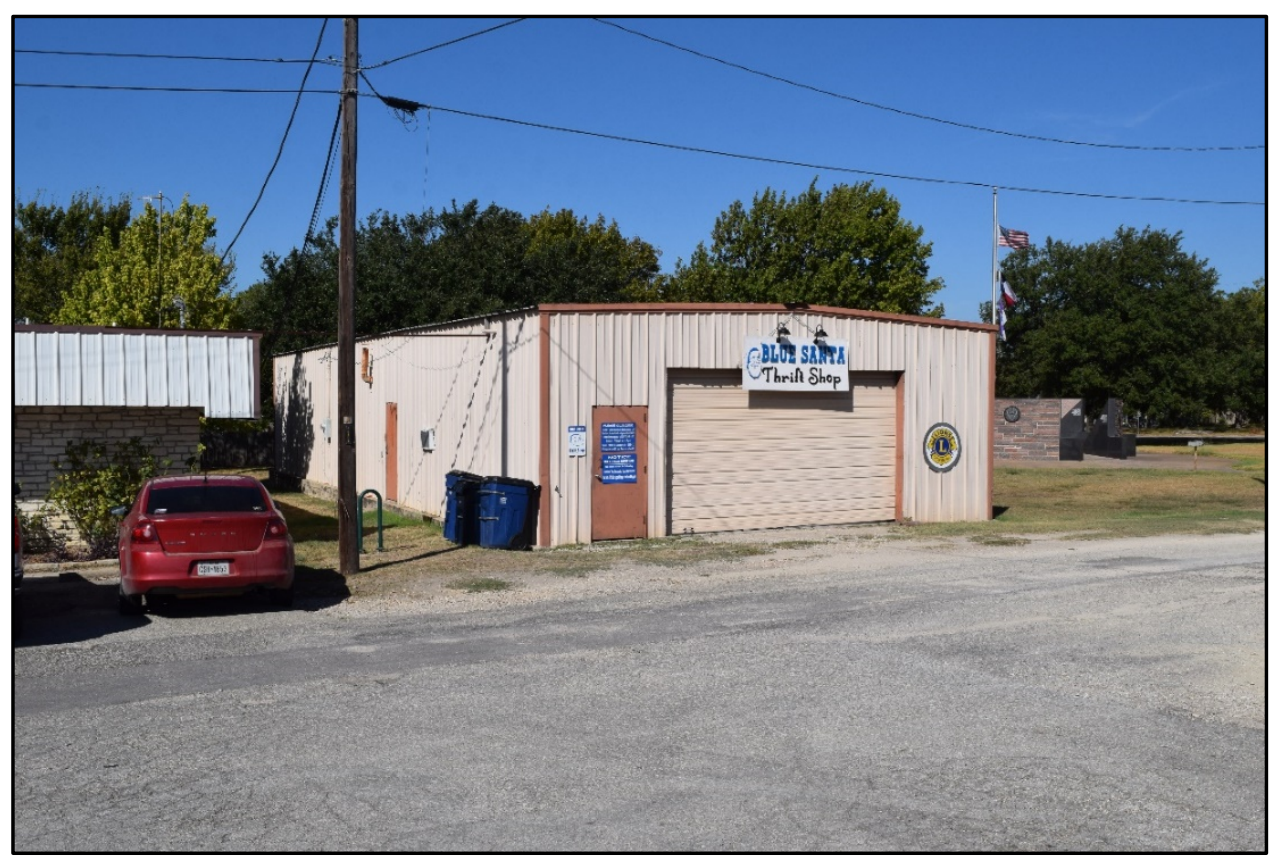

Figure 14. Storage building, oblique, east (front) and south elevations, facing northwest.

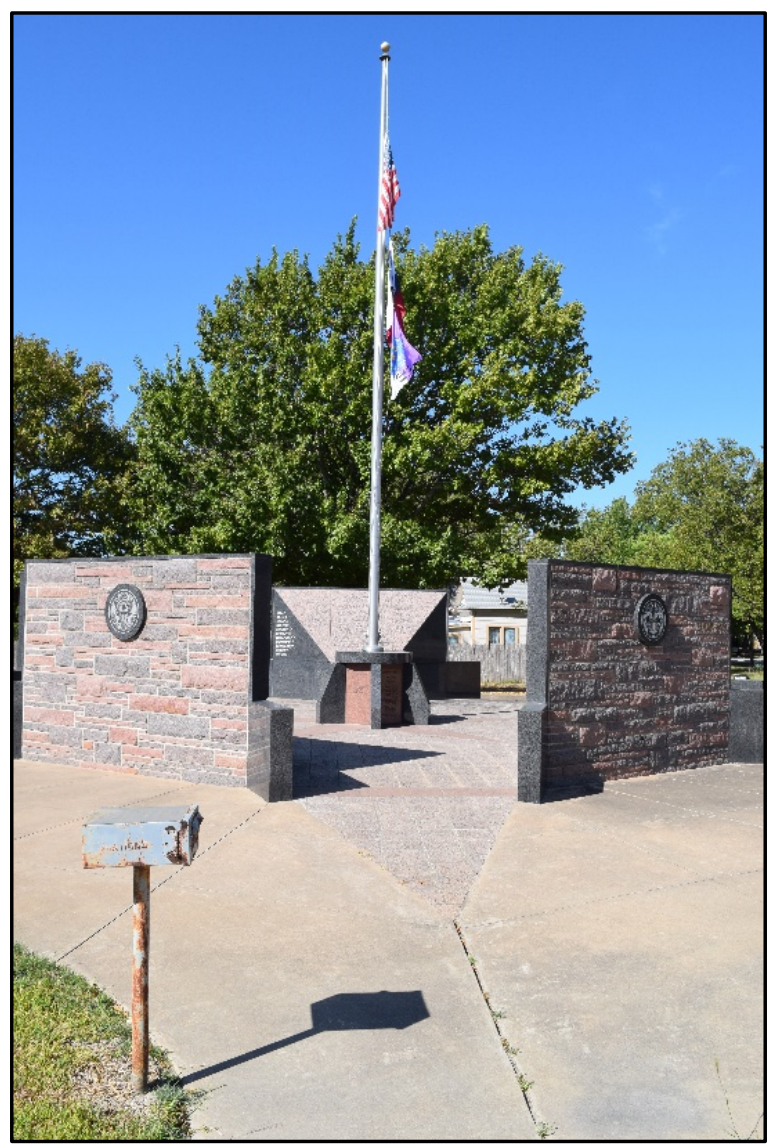

Figure 15. Veteran's Memorial, facing west. 


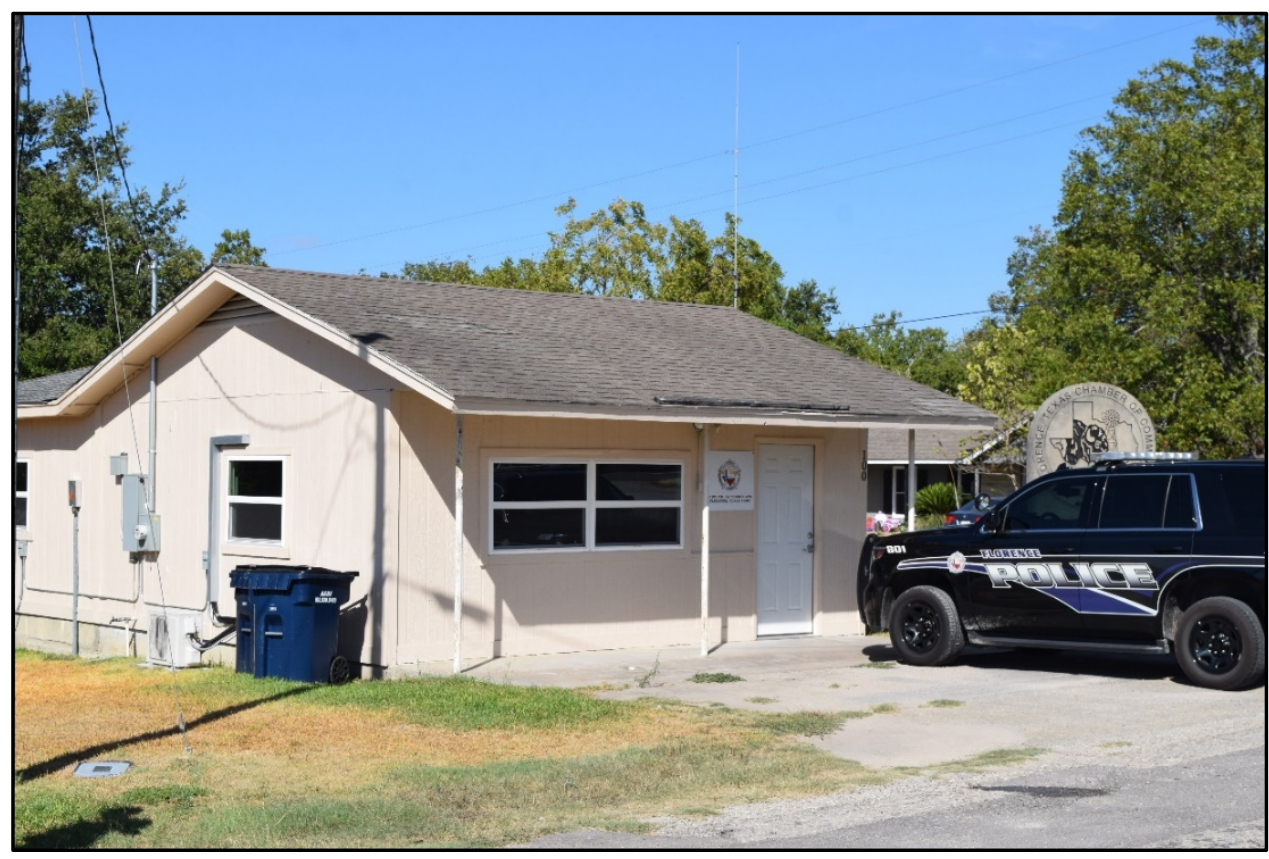

Figure 16. Chamber of Commerce, oblique, east (front) and south elevations, facing northwest.

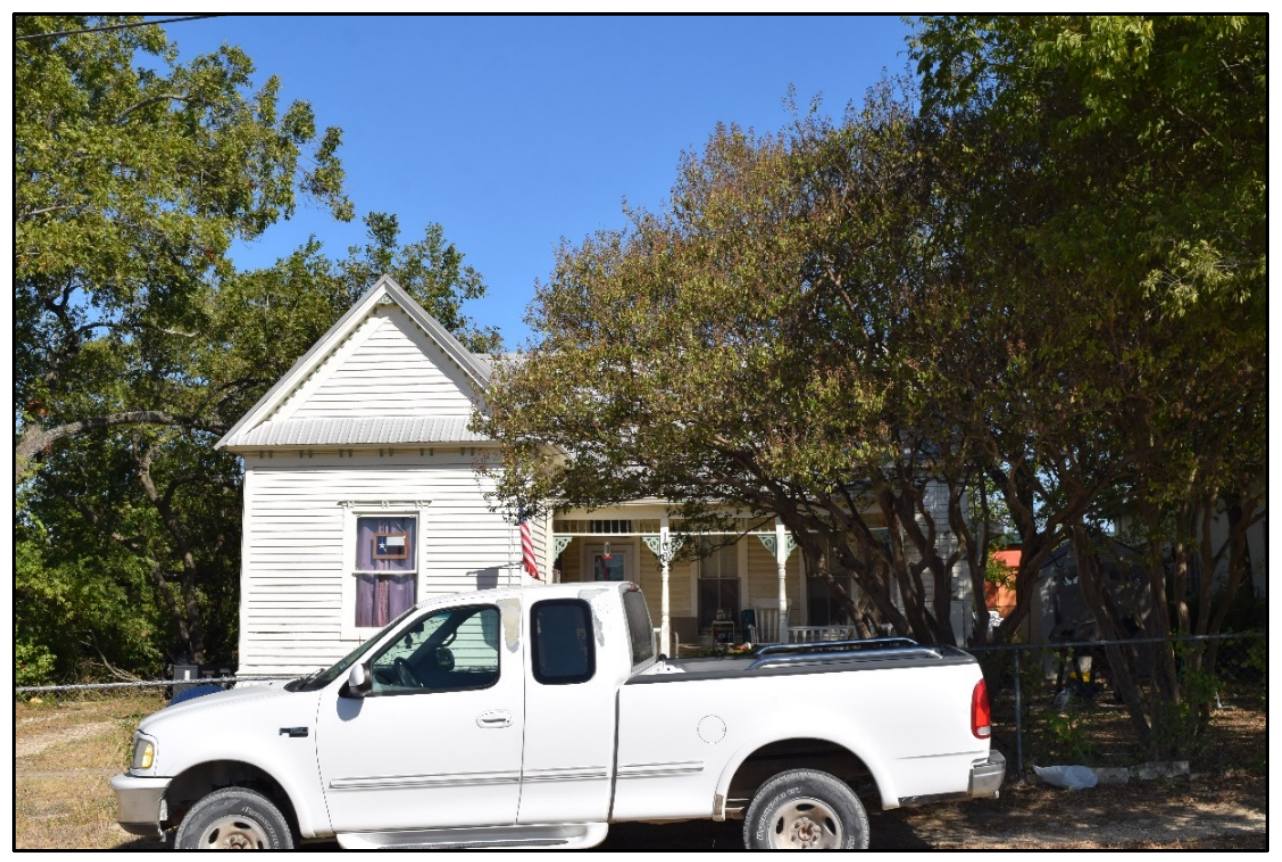

Figure 17. Historic-age residence immediately north of project area, south (front) elevation, facing north. 


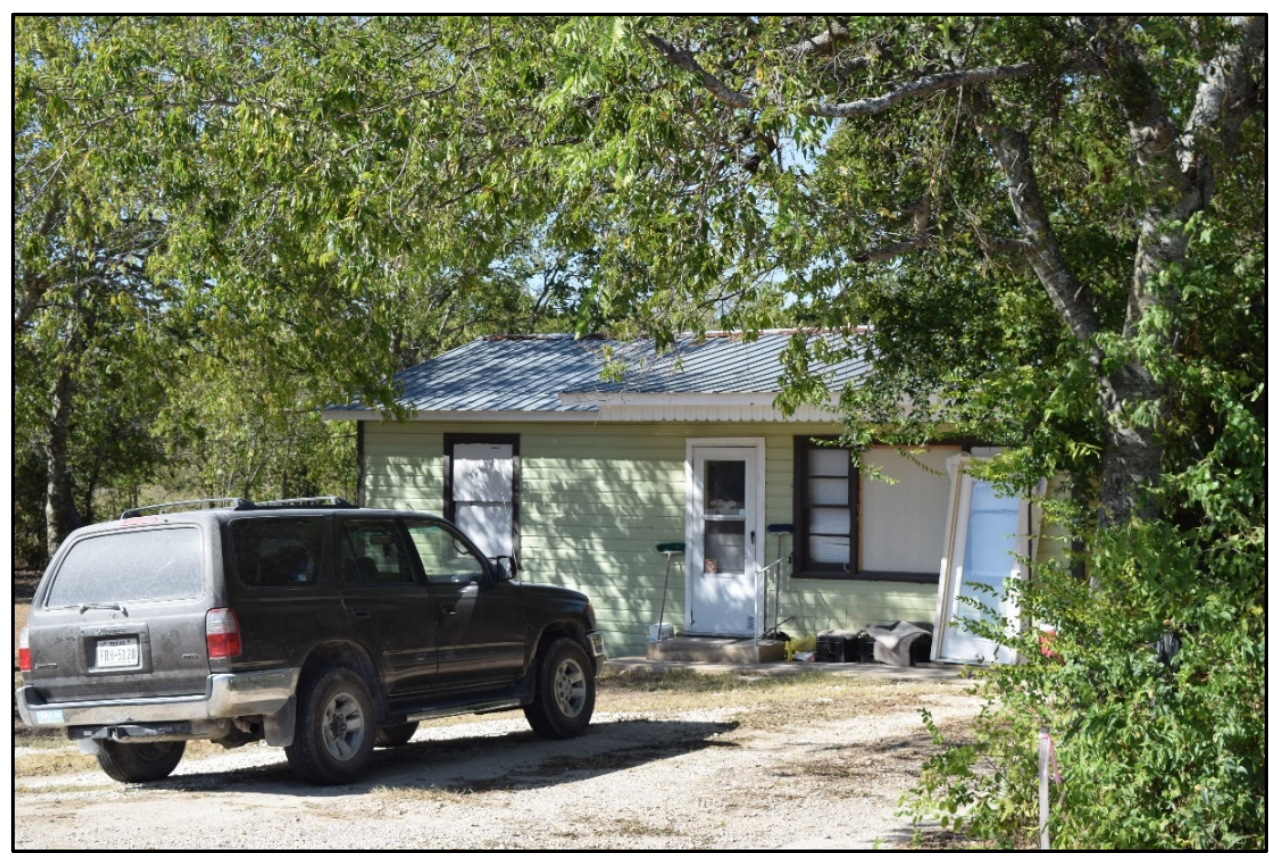

Figure 18. Historic-age residence immediately south of project area, east (front) elevation, facing southwest.

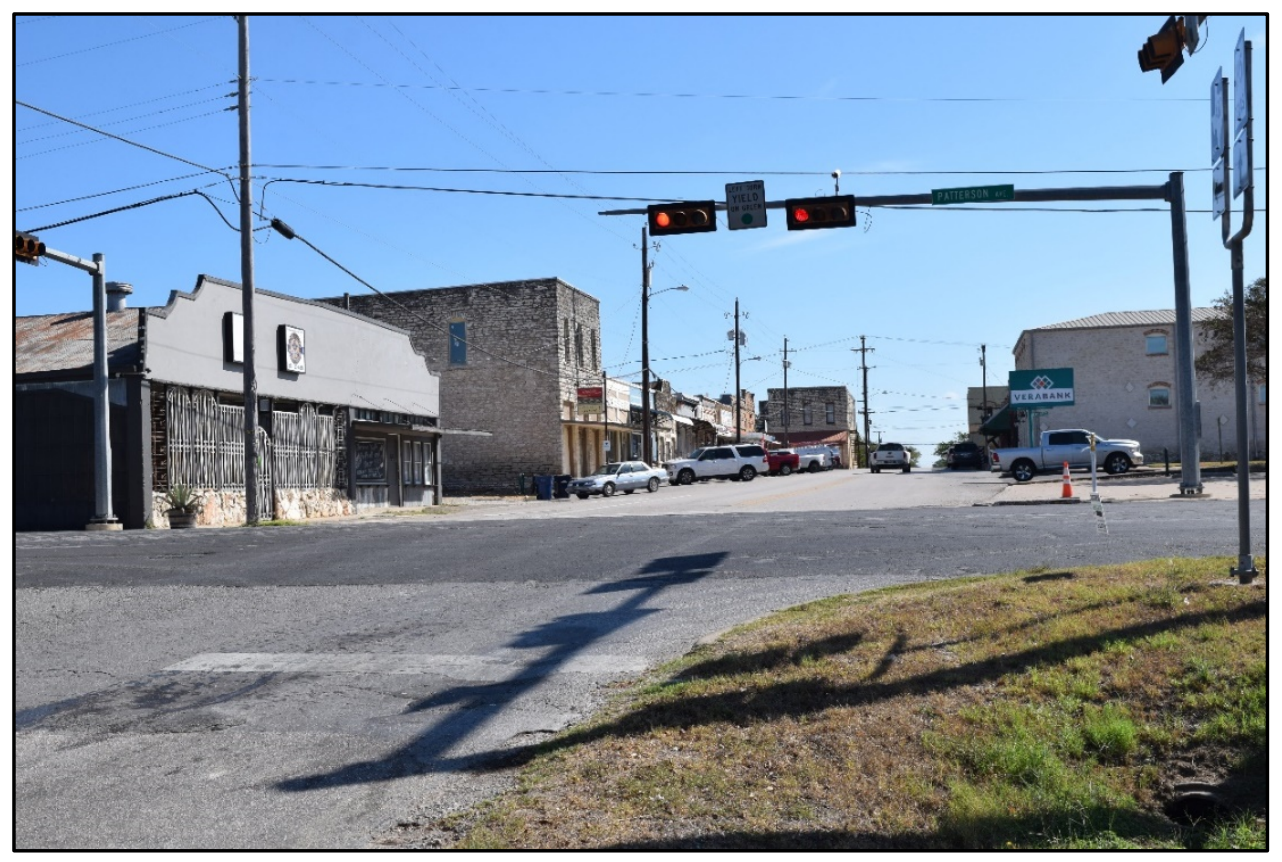

Figure 19. Main Street, view from northeast corner of project area, facing east 


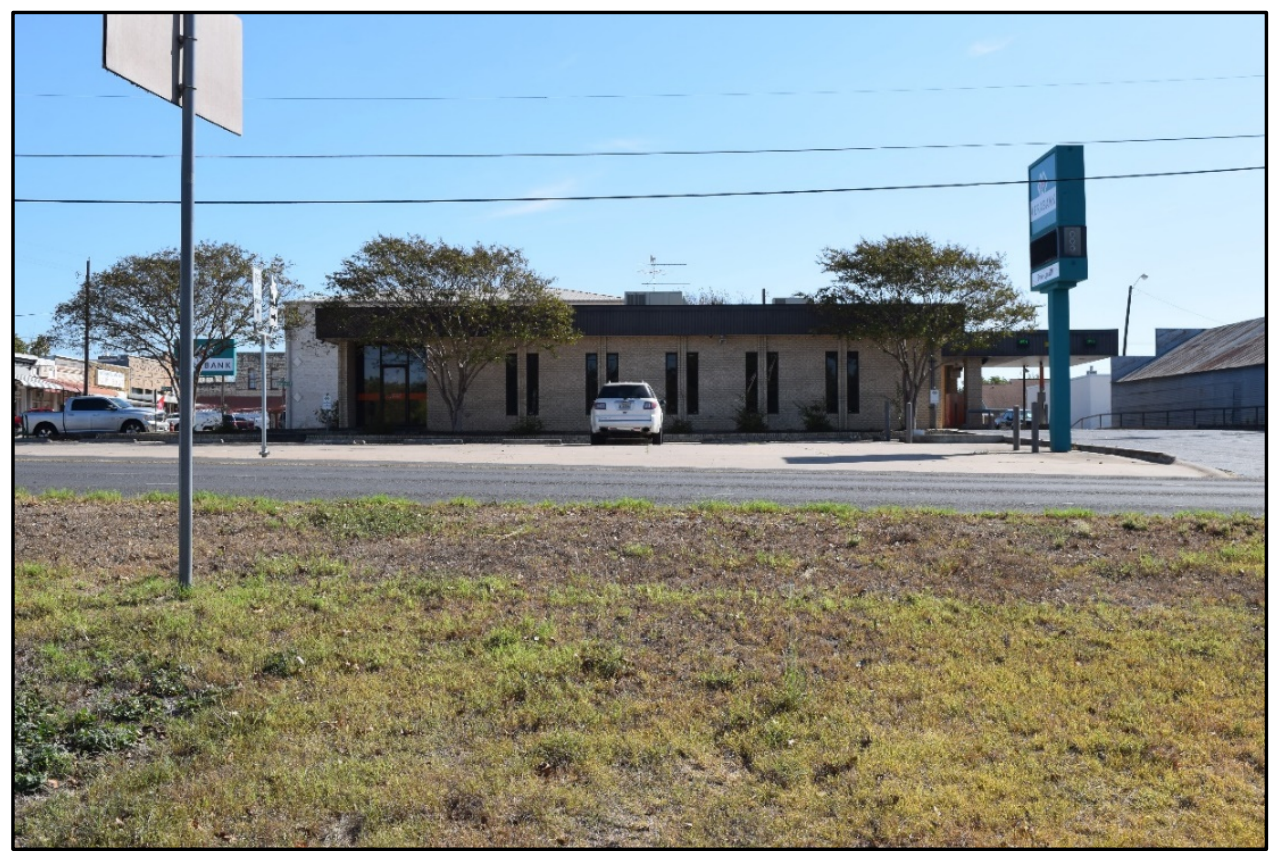

Figure 20. Modern bank building, corner of Main and Patterson, east of project area, west elevation, facing east.

\section{Tribal Coordination}

On behalf of the USDA, SWCA has submitted engagement letters to the following tribes identified by HUD as having interests which overlap with the Project area; Apache Tribe of Oklahoma, Comanche Nation of Oklahoma, Coushatta Tribe of Louisiana, Delaware Nation of Oklahoma, Tonkawa Tribe of Indians of Oklahoma, and the Wichita and Affiliated Tribes (i.e., Wichita, Keechi, Waco, and Tawakonie) of Oklahoma. To date, SWCA has yet to receive comments from the identified tribes.

\section{SUMMARY AND RECOMMENDATIONS}

On behalf of the City of Florence, SWCA conducted an intensive cultural resources survey of the proposed 1.2-acre Municipal Facilities Complex. The Project area parcel currently contains the Florence City Hall, the Chamber of Commerce, a Veteran's Memorial, and a thrift store, all of which are less than 50 years old; all but the Veteran's Memorial are destined for demolition. The cultural resources investigation consisted of a background and historical map review of a 1-mile buffer around the Project area, followed by an intensive archaeological pedestrian survey augmented by shovel testing within the Project area. SWCA's background review determined that there are no known cultural resources within the Project area. The historical map review identified numerous potentially historical structures within 350 feet of the Project area, two of which were identified within the Project area.

During field investigations on November 5, 2019, SWCA determined that the four extant buildings/structures within the Project area are of modern construction and do not meet the criteria for NRHP or SAL designation for architecture. Furthermore, no evidence for the two potential historical structures identified during the historical map review exists within the Project area. SWCA excavated a total of 12 shovel tests within the Project area, three of which were positive for cultural materials. Due to the lack of soil integrity and the potential for the recovered material to be of a modern origin, the three shovel tests have been combined to constitute an isolated find (i.e., IF01). IF01 does not rise to the level 
of an archaeological site, and therefore, does not require a trinomial from the THC. No other known cultural resources are within the Project area and no further fieldwork is recommended.

On behalf of the USDA, SWCA has issued engagement letters to the six Tribes identified by the HUD as having overlapping interest with the Project area. To date, SWCA has yet to receive comments from the identified Tribes.

In accordance with 36 Code of Federal Regulations (CFR) 800.4(b)(1), as well as the ACT, SWCA has made a reasonable and good faith effort to identify cultural resources within the Project area. The archaeologists and architectural historian recommend a finding of No Historic Properties Affected per 36 CFR 800.4(d)(1). No further archaeological investigation of the current Project area is recommended. Please refer to Appendix A for the Unanticipated Discoveries Plan. 


\section{REFERENCES CITED}

Barnes, Virgil E.

1992 Geological Atlas of Texas, Waco Sheet. Bureau of Economic Geology, The University of Texas at Austin.

Bolton, H. E.

1970 Texas in the Middle Eighteenth Century: Studies in Spanish Colonial History and Administration. The Texas State Historical Association and the University of Texas Press, Austin.

Campbell, R. B.

2003 Gone to Texas: A History of the Lone Star State. Oxford University Press, New York, New York.

Campbell, T. N.

1988 Indians of Southern Texas and Northeastern Mexico: Selected Writings of Thomas Nolan Campbell. Texas Archeological Research Laboratory, with the cooperation of the Department of Anthropology, the College of Liberal Arts, and the Institute of Latin American Studies, The University of Texas at Austin.

Castañeda, C. E.

1936-1958 Our Catholic Heritage in Texas, 1519-1936. 7 Vols. Von Boeckmann-Jones Co., Austin, Texas.

Collins, M. B.

2004 Archeology in Central Texas. In The Prehistory of Texas. Edited by Timothy K. Perttula, pp. 101-126. Texas A\&M University Press, College Station.

Find A Grave

2019 www.findagrave.com, "Florence Cemetery". Available at:

https://www.findagrave.com/cemetery/214345/florence-cemetery. Accessed November 2019.

Foster, T. R., T. Summerville, and T. Brown

2006 The Texas Historic Overlay: A Geographic Information System of Historic Map Images for Planning Transportation Projects in Texas. Prepared for the Texas Department of Transportation by PBS\&J, Austin, Texas.

Freeman, M. D.

1994 Agriculture in Texas: Ranching and Stock Farming on the Eastern Edwards Plateau, 18451941. Komatsu/Rangel, Inc., Architects and Planners, Fort Worth, Texas. U.S. Army Corp of Engineers, Fort Worth District.

Miller, M., and M. Faux (editors)

1997 The New York Public Library American History Desk Reference. The Stonesong Press, Inc. and the New York Public Library, New York, New York.

National Register of Historic Places (NRHP)

1976 National Register nomination form for the Alamo Plaza Historic District. Manuscript on file. Texas Historical Commission, Austin. 
Natural Resources Conservation Service (NRCS)

2019 Web Soil Survey. Available at: http://websoilsurvey.nrcs.usda.gov. Accessed September 2019.

Prewitt, E. R.

1981 Cultural Chronology in Central Texas. Bulletin of the Texas Archeological Society 52:65-89.

Texas Historical Commission (THC)

2019 Texas Archeological Sites Atlas restricted database. Available at:

http://pedernales.thc.state.tx.us/. Accessed September 2019.

Texas State Historical Association

2019 Handbook of Texas Online, Clara Stearns Scarbrough, "Florence, TX". Available at: https://tshaonline.org/handbook/online/articles/hlf16. Accessed November 2019.

U.S. Geological Survey (USGS)

2019 The National Geologic Map Database (TopoView). Historical topographic map collection. Available at: http://ngmdb.usgs.gov/maps/TopoView/. Accessed September 2019. 
This page intentionally left blank. 


\section{APPENDIX A}

Unanticipated Discoveries Plan 

In the event of unexpected discovery of human remains or funerary objects/contexts during construction, the City of Florence will comply with all applicable state laws (Texas Health and Safety Code Section 711, 13 TAC 22.1-22.6.), and take into account the Advisory Council on Historic Preservation's 2007 Policy Statement on the Treatment of Burial Sites. Any human skeletal remains that may be discovered will be treated with dignity and respect. If human remains are uncovered during investigations, the following steps will be taken:

- The City of Florence will halt excavation of the remains and shall notify the Williamson County sheriff and the THC. The sheriff will be requested to contact the coroner/medical examiner. After examining the human remains, if the sheriff and coroner determine the remains are modern then the sheriff or coroner will assume responsibility for the remains.

- Appropriate measures will be taken to ensure that the remains are protected and not disturbed prior to the conclusion of investigation by law enforcement and consultation with appropriate groups to determine next steps (as necessary).

- Excavations within 328 feet (100 meters) of the find will be halted until the THC authorizes continued work in those areas.

- If the Williamson County sheriff and coroner determine that the remains are not modern or a crime scene, thereby relinquishing their jurisdiction over the remains, the City of Florence will coordinate with the THC to determine the appropriate course of action and file a Notice of the Existence of a Cemetery.

Work in the affected area may resume following authorization by THC/State Historic Preservation Officer. 